\title{
A Study on The Attitudes of Business Owners Towards Learning and Their Economic Literacy: Case of Mersin
}

\author{
Ufuk Cem KOMŞU*a, Meryem Samırkaş KOMŞU ${ }^{\mathrm{b}}$, Hayat BOZc
}

\begin{tabular}{l} 
Article Info \\
\hline DOI: $10.14686 /$ buefad.404472 \\
\hline Article History: \\
Received: $\quad 12.03 .2018$ \\
Accepted: 15.04 .2018 \\
Published: $\quad 30.06 .2018$ \\
\hline Keywords: \\
Attitude towards learning, \\
Economic literacy, \\
Lifelong learning, \\
Business owners. \\
\hline Article Type: \\
Research article \\
\end{tabular}

\begin{abstract}
It might be observed that economic literacy of individuals play a critical role mostly for people who run a business under the economical conditions of contemporary world where many kinds of literacies required. Hence, the learning and attitude towards learning activities have become key instruments for such circumstances. The business owners in Mersin was the population of this study with the aim of determining effections between attitudes towards learning and economic literacy and changes related to some demographical variables. With the sample of 330 participants, the data of this research was obtained via a questionnaire consisting of demographic questions and scales of attitude towards learning and economic literacy. The findings have shown that the economic literacy of the business owners is influenced by the attiudes towards learning. It was also determined that the age, the level of education and the duration of experience at work may have an effect on economic literacy and attitudes towards learning. As a result of findings, it can be inferred that positive learning attitude may increase level of economic literacy and both scores of attitude towards learning and level of economic literacy may increase as the age, the education level and the duration of work experience increase.
\end{abstract}

\section{İşyeri Sahiplerinin Öğrenmeye İlişkin Tutumları İle Ekonomi Okuryazarlığı Düzeyleri Üzerine Bir İnceleme: Mersin Örneği}

\begin{tabular}{l} 
Makale Bilgisi \\
\hline DOI: \\
10.14686/buefad.404472 \\
\hline Makale Geçmişi: \\
Geliş: $\quad 12.03 .2018$ \\
Kabul: $\quad 15.04 .2018$ \\
Yayın: $\quad 30.06 .2018$ \\
\hline Anahtar Kelimeler: \\
Öğrenmeye yönelik tutum, \\
Ekonomi okuryazarlığı, \\
Yaşamboyu öğrenme, \\
İşyeri sahipleri. \\
\hline Makale Türü: \\
Araştırma makalesi \\
\end{tabular}

Öz

Çok çeşitli okuryazarlık türlerinin gerekliliğinden söz edildiği günümüzde, dünya ekonomisinin bugünkü şartlarıyla bir işyerini işletmekte olan bireyler açısından ekonomi okuryazarlığının kritik bir önem taşıdığı gözlemlenebilmektedir. Dolayısıyla, öğrenme ve öğrenmeye yönelik tutumlar, bu koşullar altında kilit rol oynayan araçlar haline gelmiştir. Öğrenmeye ilişkin tutum ile ekonomi okuryazarlığ arasındaki etkileşimi ve bunların bazı demografik değişkenlere göre değişimini belirlemeyi amaçlayan bu çalışmanın araştırma evreni, Mersin'deki işyeri sahipleridir. Araştırmanın verileri demografik bilgiler, öğrenmeye ilişkin tutum ve ekonomi okuryazarlığı ölçeklerinden oluşan bir soru dizisi aracılığıyla, 330 katılımcıdan oluşan bir örneklemden toplanmıştır. Bulgulara göre, işyeri sahiplerinin öğrenmeye ilişsin tutumları, onların ekonomi okuryazarlığını etkileyebilmektedir. Ayrıca, işyeri sahiplerinin yaşının, eğitim düzeyinin ve işlerindeki deneyim sürelerinin de ekonomi okuryazarlığı düzeylerini ve öğrenmeye ilişkin tutumlarını etkileyebildiği saptanmıştır. Bu sonuçlara göre, öğrenmeye yönelik olumlu tutumların ekonomi okuryazarlığı düzeyini artırabileceği, ayrıca hem öğrenmeye ilişkin tutum hem de ekonomi okuryazarlığ 1 değerlerinin yaş, eğitim düzeyi ve iş deneyimiyle birlikte artabileceği söylenebilir.

\footnotetext{
*Corresponding Author: ucemkomsu@mersin.edu.tr

a Dr., Mersin University, Mersin/Turkey, http://orcid.org/0000-0002-8348-8747

${ }^{\mathrm{b}}$ Assoc. Prof. Dr., Mersin University, Mersin/Turkey, http://orcid.org/0000-0002-3264-5896

${ }^{\mathrm{c}}$ Assoc. Prof. Dr., Ankara University, Ankara/Turkey, http://orcid.org/0000-0001-5409-8371 562
} 


\section{Introduction}

There is no doubt that those who are most exposed to the effects of the high dynamics of economic life are business owners. This part of the society carries the most critical functions of today's economy on their shoulders. It will not be wrong to argue that the ability to establish an economic activity and/or to sustain it with all its costs and obligations contributes to the preservation of socio-economic balances.

Being responsible for the operation and management of a workplace, whether it is a small, medium-sized company or being a tradesman, requires some technical knowledge and skills. For this reason, there are different competencies and skills that individuals who have started and operating a business need to have compared to the individuals from other segments of the society, such as a student, a government official or a housewife. Various types of literacy, considered to be the current facts of the lifelong learning philosophy, has gained importance because of the fact that such knowledge and skills cannot be acquired through formal education systems. One of them being economic literacy has a critical function with its every dimension.

However, it can be argued that the concretization of such a function depends on the ability of the individual to perceive the knowledge and skills needed by the individual and to direct the necessary learning activities. Therefore, economic literacy alone cannot be considered as a sufficient criterion or a target. A business owner should also have a positive perspective to learning and to achieving self-improvement by learning. For this reason, the attitude towards learning that expresses the interests and tendencies of individuals to learning activities may have positive or negative effects on economic literacy. Because gaining the knowledge, skills and competencies needed by different professional groups or segments of society depends on the presence of positive attitudes towards learning. Finally, there was no research found on the attitudes of the business owners towards learning and the economic literacy of them. In this context, it is thought that this research can contribute to the process of developing educational programs for different types of literacy for individuals from different occupational groups, meeting the need at an interdisciplinary level.

The aim of this study is to determine the affections between learning attitudes and economic literacy levels, by considering some demographic variables of business owners who are engaged in an economic activity. The research questions of this study are as follows:

- Does the attitude of business owners towards learning affect their economic literacy? learning?

-Do age, gender and marital status of business owners affect their economic literacy and attitudes towards

-Does the level of education of business owners affect their economic literacy and attitudes towards learning?

-Does the monthly income level of business owners affect their economic literacy and attitudes towards learning?

-Does the the duration of work experience of business owners affect their economic literacy and attitudes towards learning?

\section{Economic Literacy}

In line with the economic developments and financial liberalization around the world and the increasing integration of individuals into the financial system and the increasingly complicated economic decision-making process, the knowledge and related skills of the individuals on this issue have become more important. In this context, economic literacy, has an important place both in terms of markets and the development and effectiveness of the country and world economy (Ergün et al., 2014) Nevertheless, it can be argued that the economic knowledge and skills that can carry such a critical role cannot be acquired well enough by different social segments, and even the ignorance of individuals in this subject can be exploited. One of the best examples of this is Kim (2012)'s, a survey of under-educated adults. According to the findings of this research, it was observed that even lay learners of adult population can make right decisions on economic and political issues in accordance with their socioeconomic status when a teaching program of economic literacy with appropriate methods applied. Such findings might be regarded as an emphasize on functionality and inclusive content of economic literacy.

The economic literacy phenomenon affects individuals from all segments of life. Individuals wishing to obtain maximum benefit with limited resources at hand are expected to have a certain level of economic literacy. This requirement becomes even more apparent with the changes taking place in the financial markets and in the demographic structure of the society. Moreover, the increasing diversity of financial instruments has increased the importance of economic literacy (Kahya and İmamoğlu, 2015). The concept of economic literacy is defined in different forms in different disciplines and is often used in the same sense with the concept of financial literacy. While economic literacy is expressed as the people's level of knowledge about the economy in some definitions, 
in other definitions it is stated more comprehensively and the economy is taken into consideration as well as the skills. (Şantaş and Demirgil, 2015).

There are many different definitions of the concept of economic literacy in the literature, and one of the most extensive definitions was made by the North Central Regional Educational Laboratory (2003). According to this definition; economic literacy:

...is the ability to identify the problems that arise in the field of economy and the emerging advantages, to follow the changes taking place in economic conditions and public policies, to be able to collect and organize economic data, to consider the cost-benefit aspect of financial events "(As cited in Ünal et al., 2015: 34).

Burkhardt et al. (2003) defined the concept of economic literacy as the ability to identify economic problems, alternatives, prices and benefits, analyze incentives at work, assess the consequences of changes in local politics, collect, organize economic evidence, calculate the amount of money coming from the profits (as cited in Akhan, 2013: 4). Economic literacy, also defined as the ability to interpret economic developments and the effects of these developments on different areas such as unemployment, individual spending, financial activities, provides individuals with the following knowledge in general:

- To be able to make more informed choices by evaluating profit, cost and resources as producer, consumer and investor

- To evaluate the profit and loss of each method by separating services and gains

- To be able to define economic motivation affecting individual behaviors

- To understand how the interaction between competition, trade barriers, shortage, extremism and producer-consumer reflects on prices

- To be able to define the roles of public and private economy institutions

- To be able to understand risk, investment, unemployment, inflation and interest rates as well as income distribution and its basis

- To be able to evaluate the benefits and harms of alternative public policies

- To understand the value of entrepreneurship and the role of small and large-scale businesses in economy (Gerek and Kurt, 2011; NCREL, 2017)

When studies on economic literacy are examined, the study of Jappelli (2010) covering 55 countries catches the eye. In this international study, it was seen that the level of economic literacy of the individuals was low and there was no interest even in basic economic concepts. The findings of this research, which included comparative analysis, show that economic literacy is linked to per capita income levels and that economic literacy of individuals can be improved by strengthening social security systems. This situation is also parallel to the PISA test results conducted in various countries (Jappelli, 2010). The study of Schug and Hagedorn (2005) revealed that educational programs related to economics at the level of primary education are positive influences on basic economic issues such as spending and saving. Mercan et al.'s (2012) study on the measuring the literacy level of 93 people working at a branch of the Ministry of Transport in Turkey obtained significant relations between the level of education and economic literacy. 85 of the people participating in the survey have either a bachelor's or a graduate degree. Employees participating in the survey was found to be economically literate at a high level in terms of individual economic use. In the study conducted by Şantaş and Demirgil (2015) in order to determine the level of economic literacy of first and fourth year students in the Faculty of Economics and Administrative Sciences of a state university, it was found that male students who study in the economic and finance departments aged 22 and over and follow economic and financial developments every day have a higher perception of economic literacy.

\section{Attitude Towards Learning}

Learning is, with its most common definition, permanent behavioral changes that result from interaction with the individual's environment. The nature and functionality of these behavioral changes will bring about change and development together (Senemoğlu, 2009). Such a result depends on the attitudes of the individual. Attitude refers to the psychological tendencies composed of a person's positive or negative evaluations for the world around him (Chang and Chang, 2013). According to another definition, attitude is the mental and emotional state that affects people's thoughts and behaviors (Shih et al., 2011). With this definition, attitude towards learning or learning attitude can be regarded as the tendency of individuals to learning activities.

The ability of adult individuals to solve the problems encountered in the course of everyday social life and to be able to develop by changing oneself with every experience depends on having positive feelings and thoughts 
towards learning. Indeed, there are several research findings which reveal that individuals' approaches to learning influence learning outcomes and achievement levels. According to this, it can be said that the success and development levels of the individuals who are more open to learning and less anxious about learning are higher than those of others (Aydın, 2016; Kara, 2010). According to Hsu, the learning attitude is determinative of all the individual learning activities of the individual. Thus, the attitude towards all the people, the events and the objects, such as the teacher and learning materials involved in the learning activities of a student, can also affect his learning behavior and his success in the learning process. Hence, the learning attitude includes cognitive (beliefs or knowledge about things around the person), affective (feelings of sympathy, pleasure, etc.) and behavioral components (making or refusing learning activities) (as cited in Chang and Chang, 2013). In this context, a student may have an active and effective attitude towards participating in learning and understanding activities when he is really interested in learning (Chang and Chang, 2013). As a matter of fact, Chang and Chang (2013) also found a high correlation between learning motivation and learning attitude.

The findings of some studies with target groups of students and teachers showed that there is no universally valid attitude towards computer and internet-based learning activities. However, such an attitude has affective, cognitive and behavioral dimensions (Liaw et al., 2007). Recent studies on teachers' learning attitudes are mostly based on computer and internet use. For example, the research of Kao and Tsai (2009) examined the psychological factors that affect teachers' attitudes towards learning and teaching using computers and the Internet. According to the results of Aktürk (2012) 's research in which he examined the teachers' attitudes towards learning in terms of professional preference and academic success, it was found that those who preferred the teaching profession for internal reasons (such as idealism) have a much more positive attitude towards learning and have fewer anxieties about learning than those who were directed towards the profession by environmental factors. In the study of Aydin (2016), once again on the teacher candidates, it was determined that the attitudes of the science teachers towards learning were high and positive, and while the female teacher candidates were more open to learning, the male teacher candidates had lower levels of anxiety regarding learning.

As a result, when the related literature was analyzed, it was found that there are many studies examining the attitudes of students, teacher candidates, teachers and academicians in relation to learning and that there is no study regarding the workplace or the business owners.

\section{The Interaction Between Attitude Towards Learning and Economic Literacy}

As the researches examining the learning and education studies within the formal education show, the results of the learning activities of individuals who demonstrate a positive attitude towards learning can be more efficient and effective than the others. From the fact that the positive feelings and thoughts about learning increase the success in the learning process, it is expected that the individuals who show a positive attitude towards learning will also succeed in the acquisition of various literacy types. Thus, it is possible that there is a positive correlation between learning attitude and economic literacy. The existence and level of such a relationship will play a positive role in adult learning and adult education in connection with various literacy competencies.

It is imperative that non-formal education programs be developed to meet the needs of the growing economic literacy in society. The precondition for the development of such training programs is to determine training needs. Such needs can emerge in different forms in different parts of the society (Temizel and Bayram, 2011). For example, the knowledge and skills that university students need in the context of economic literacy and the knowledge and skills that business owners need to run a business can vary. However, in order to obtain the latest knowledge and skills, it is necessary first to have a positive attitude towards learning. Therefore, the level of economic literacy of a business owner living in Turkey and independently operating a business on their own may be related to both the perception of learning needs and the attitude towards learning.

\section{Method}

Under this heading, the researcher provided information on the design of the research, the size of the population and sample and the data collection tool with analysis of the data. Firstly, the research design and population and sample were included; next the participants who constitute the sample and the structure of the questionnaire as data collector and the quantitative analysing techniques were described. 


\section{Research Design}

When introducing a research's design, describing and defining the variables and research techniques provides descriptive information about the scope of the research. Within this study the structure of the research problems and the research purpose necessitated the application of quantitative analysis techniques. Most of quantitative researches might be classified into two groups: Descriptive and casual comperative researches (Balc1, 2010). This quantitative research might be regarded as both descriptive and casual comperative due to the aim of the study and research questions. In accordance with the aim and the research questions the main dependent variable of the research is economic literacy of business owners. Besides, both economic literacy and the attitude towards learning play the roles of both dependent and independent variable under the conditions of some demographic independent variables. Hence, such structure required using correlational and regression analysis.

\section{Population and Sample}

The population of the survey is the owners of workplaces that can be classified as stores, shops or offices being operated in the Mersin province. Within this framework, because of the fact that the number of active enterprises in Mersin province is 50.630 (TESK, 2017), the sampling size was determined based on statistical calculations to be 381 at $95 \%$ confidence interval (Altunış1k et al., 2010). However, as a result of the survey which was carried out by reproducing 385 forms and assigning four interviewers plus two researchers, the number of eligible survey forms remained at 330 and thus the size of the study group became 330, due to the widespread problems encountered in field surveys. Lastly, the participants who formed the study group were determined by random sampling method.

Chracteristics of the participants. The study group which consists of the participants who were randomly selected includes 330 business owners. In this section, firstly the variables of business owners' job, age, gender, education level, marital status, financial situation and experience presented. Second, participants' scores on attitude towards learning and economic literacy are displayed.

Table 1 shows some demographic data related to the objective of this study. The participants' age, gender, educational level, marital status, monthly income and duration of experience variables are listed in order to exhibit the demographical profile.

Table 1. Distribution of Some Demographic Characteristics of the Business Owners

\begin{tabular}{|c|c|c|c|}
\hline Variable & Groups & Frequency (f) & Percent (\%) \\
\hline \multirow{7}{*}{ Age (year) } & $18-25$ & 26 & 7.9 \\
\hline & $26-35$ & 74 & 22.4 \\
\hline & $36-45$ & 123 & 37.3 \\
\hline & $46-55$ & 75 & 22.7 \\
\hline & $56-65$ & 23 & 7 \\
\hline & $66-75$ & 9 & 2.7 \\
\hline & Total & 330 & 100 \\
\hline \multirow{3}{*}{ Gender } & Female & 56 & 17 \\
\hline & Male & 274 & 83 \\
\hline & Total & 330 & 100 \\
\hline \multirow{9}{*}{$\begin{array}{l}\text { Educational } \\
\text { Background }\end{array}$} & Primary school drop out & 6 & 1.8 \\
\hline & Primary school & 51 & 15.5 \\
\hline & Secondary school & 78 & 23.6 \\
\hline & High school & 109 & 33 \\
\hline & Vocational high school & 10 & 3 \\
\hline & Associate degree & 28 & 8.5 \\
\hline & $\begin{array}{l}\text { Bachelor's degree and } \\
\text { higher }\end{array}$ & 48 & 14.5 \\
\hline & Table 1 continuation & & \\
\hline & Total & 330 & 100 \\
\hline \multirow{4}{*}{ Marital Status } & Married & 251 & 76.1 \\
\hline & Single & 79 & 23,9 \\
\hline & Total & 330 & 100 \\
\hline & $0-2000$ & 66 & 20 \\
\hline
\end{tabular}




\begin{tabular}{llcc}
\hline & $2001-4000$ & 132 & $\mathbf{4 0}$ \\
Income (TL, & $4001-6000$ & 71 & 21.5 \\
monthly) & $6001-8000$ & 30 & 9.1 \\
& $8001-10000$ & 16 & 4.8 \\
& $10000+$ & 15 & 4.5 \\
& Total & 330 & 100 \\
\hline & $0-5$ & 85 & $\mathbf{2 5 . 8}$ \\
Job Experience & $6-10$ & 74 & 22.4 \\
(Year) & $11-15$ & 71 & 21.5 \\
& $16-20$ & 41 & 12.4 \\
& $21-25$ & 24 & 7.3 \\
& 25 years and above & 35 & 10.6 \\
& Total & 330 & 100 \\
\hline
\end{tabular}

As can be seen from Table 1, the weight of the participants according to their age distribution is in the range of $26-45$ years and the share of these two groups is $59.7 \%$. Men are the majority with an $83 \%$ share in terms of the gender of participants. The distribution of the participants according to their education levels are as follows: high school graduates $(33 \%)$, secondary school graduates $(23.6 \%)$ and primary school graduates $(15.5 \%)$. The vast majority of participants were married $(76.1 \%)$. According to the income level distribution, those who declared a monthly income in the range of 2.001-4.000 TL were $40 \%$ and the share of those who declared a monthly income in the range of 4.001-6.000 TL was $21.5 \%$. The share of those who declared a monthly income of $2.000 \mathrm{TL}$ or less was $20 \%$. According to the distribution of experience in economic activity, the weighted accumulation was in the range of $0-15$ years. According to the duration of experience of the participants, the highest frequency was in the newly established businesses between $0-5$ years $(25.8 \%)$. The share of those who operate a long-established business for longer than 20 years $(7.3 \%+10.6 \%)$ is $17.9 \%$. According to this, there is a study group composed of married men, mostly with high school education levels or lower levels, who have little experience with the work they are currently engaged in. This profile may reflect the characteristics of tradesmen and small to medium-sized businesses in Turkey.

In addition, the 41-item list that developed by Mersin Chamber of Commerce and Industry for classifying economic activities was used for survey coding, and 26 of them were included in the sample. The highest frequency activities in this distribution that were not placed on the table due to the length of the list are as follows: $23.6 \%$ of the participants deal with restaurants-cafeteria-patisseries, $15.8 \%$ deal with retail food and miscellaneous trade, 13.9\% deal with Travelling, Accomodation, Entertainment, Arts and Sports Enterprises; 7.6\% of them deal with Textile Garment and Shoes Trade; 7.3\% of them deal with Computer Electricity Electronic Telecommunications and Office Equipments; 3.9\% deal with Furniture, Carpet and Household Goods; 3.6\% deal with Stationery, Printing House, Advertising, Press, and Publishing Services and the rest carry out other economic activities.

Participants' scores on attitude towards learning and economic literacy. It would be useful to demonstrate economic literacy and attitude scores on learning before analyzing some demographic variables of the participants of the study group. Table 2 shows the descriptive statistical values of participants' attitudinal scores on both economic literacy and learning.

It was found that the level of "knowledge on economics" of the business owners who participated in the survey was moderate (3.294 \pm 0.945$)$. The level of "economic Rationality" was high (3.838 \pm 0.927$)$. The level of "social economic reflections" was high, $(3.953 \pm 0.795)$. The level of "individual economic planning" was very high (4.306 \pm 0.842$)$. "General level of economic literacy" was high $(3,694 \pm 0,737)$ and the level of "attitude towards learning" was very high $(4.220 \pm 0.721)$. This profile shows that in contrast to the participants' level of economic literacy being moderate, the level of attitude towards learning is much higher. It can be said that such a structure is positive for a majority of people with high school or lower education levels.

Table 2. Descriptive Scores for Economic Literacy and Attitude Towards Learning

\begin{tabular}{lccccc}
\hline Items & N & Mean & SD & Min. & Max. \\
\hline Knowledge on Economics & 330 & 3.294 & 0.945 & 1.000 & 5.000 \\
Economic Rationality & 330 & 3.838 & 0.927 & 1.000 & 5.000 \\
Social Economic Reflections & 330 & 3.953 & 0.795 & 1.380 & 5.000 \\
Individual Economic Planning & 330 & $\mathbf{4 . 3 0 6}$ & 0.842 & 1.000 & 5.000 \\
General Economic Literacy & 330 & 3.694 & 0.737 & 1.700 & 5.000
\end{tabular}




$\begin{array}{llllll}\text { Attitude Towards Learning } & 330 & \mathbf{4 . 2 2 0} & 0.721 & 1.220 & 5.000\end{array}$

\title{
Data Collection Tools
}

The data collection tool of this research is a three-part questionnaire. A questionnaire with 49 items was used in the survey. In the first part of the questionnaire, there was a form consisting of basic demographic questions, the Economic Literacy Scale was covered in the second part and the Learning Attitude Scale was covered in the last part. The survey was conducted by interviewing the business owners who agreed to contribute to the survey.

The "Expectation" subscale which represents the perception of learning before action, of 4 sub-dimension "Learning Attitude Scale", which was developed by Kara (2010), was selected as the Learning Attitude Scale. "The Economic Literacy Scale" is a 4-dimensional scale developed by Gerek and Kurt (2011), all of which are used in the questionnaire form. This scale is composed of the subscales of "Economic Information", "Economic Rationality", "Social Economic Reflections" and "Individual Economy Planning". Likert-type five-item ratings were used for both scales.

In this study, the reliability of the Economic Literacy Scale was very high with Cronbach's Alpha $=0.949$ and the reliability of the Learning Attitude Scale was found to be high with Cronbach's Alpha $=0.881$.

\section{Data Collection}

The survey was carried out by four college students as pollsters plus two of researchers. The pollsters omitting the researchers consist of the college students who were volunteer for the survey, of Vocational School of Erdemli. It required two stage courses which lasted 3-4 hours to train the students. Firstly in the courses, the ways of introducing a research, convincing someone to join a survey and the basis of conducting a poll were disscussed. After that, first trials were applied to students' contacts, then the main process was started and it lasted a month to complete.

The sampling area which includes the city of Mersin's inhabitants was divided into 6 different parts in accordance with the number of pollsters totaly. Each student was to bring the completed questionnaires conducted from his/her area and the collected questionnaires were checked then recorded daily. The number of eligible questionnaires remained at 330 and thus the size of the study group became 330 due to the widespread problems encountered in field researches such as misperceiving, misunderstanding, interruptions or overeacting of prospective participants.

\section{Data Analysis}

The structure of the research problems and the research purpose necessitated the application of quantitative analysis techniques. The data obtained in the study were analyzed using SPSS (Statistical Package for Social Sciences) for Windows 22.0 program. Number, percentage, mean and standard deviation were used as descriptive statistical methods in the evaluation of the data. The scores of scale dimensions were evaluated between 1 and 5 . For the calculation of the distribution range, the formula of. Distribution Range= Maximum value-Minimum value / number of degrees was used. This range is 4 points wide. This width is divided into five equal widths and interpreted, ranging from 1.00 to 1.79 "very low", between 1.80 and 2.59 "low", between 2.60 and 3.39 "medium", between 3.40 and 4.19 high, between 4.20 and 5.00 very high, (Sümbüloğlu, 1993).

The t-test was used to compare quantitative continuous data between two independent groups, and the One Way ANOVA test was used to compare quantitative continuous data between more than two independent groups. After the Anova test, the Scheffe test was used as a complementary Post-Hoc analysis to determine the differences. Pearson Correlation and regression analysis were applied for the relationship between the continuous variables of the study. The findings were evaluated at the $95 \%$ confidence interval and at the $5 \%$ significance level.

\section{Findings}

In this section, findings obtained by analyzing the data obtained through data collection are exhibited and on the basis of research purposes. In this context, firstly, the findings related to the first problem of this research is presented, then the findings related to the other research problems were introduced.

\author{
The Effect of Business Owners' Attitude Towards Learning on Economic Literacy
}


The first problem of our research was "Do the attitudes of the business owners towards learning affect economic literacy?" Both correlation and regression analyzes were utilized to answer this question. Table 3 shows the correlation values explaining the direction and level of the relationship between attitudes towards learning and economic writing. Table 4 shows the results of a regression analysis showing the cause-effect relationship between the attitudes towards learning and the economic literacy.

Table 3. Correlation Analysis Between The Attitudes Towards Learning and Economic Literacy

\begin{tabular}{|c|c|c|c|c|c|c|c|}
\hline Items & & 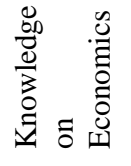 & 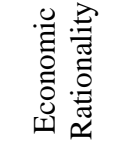 & 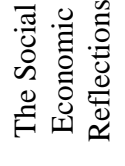 & 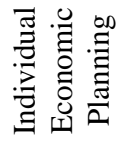 & 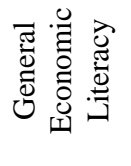 & 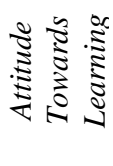 \\
\hline \multirow{2}{*}{ Knowledge on Economics } & $\mathrm{r}$ & 1.000 & & & & & \\
\hline & $\mathrm{p}$ & 0.000 & & & & & \\
\hline \multirow{2}{*}{ Economic Rationality } & $\mathrm{r}$ & $0.600 * *$ & 1.000 & & & & \\
\hline & $\mathrm{p}$ & 0.000 & 0.000 & & & & \\
\hline \multirow{2}{*}{ Social Economic Reflections } & $\mathrm{r}$ & $0.479 * *$ & $0.711 * *$ & 1.000 & & & \\
\hline & $\mathrm{p}$ & 0.000 & 0.000 & 0.000 & & & \\
\hline \multirow{2}{*}{ Individual Economic Planning } & $\mathrm{r}$ & $0.228 * *$ & $0.451 * *$ & $0.550 * *$ & 1.000 & & \\
\hline & $\mathrm{p}$ & 0.000 & 0.000 & 0.000 & 0.000 & & \\
\hline \multirow{2}{*}{ General Economic Literacy } & $\mathrm{r}$ & $0.860 * *$ & $0.879 * *$ & $0.805 * *$ & $0.518 * *$ & 1.000 & \\
\hline & $\mathrm{p}$ & 0.000 & 0.000 & 0.000 & 0.000 & 0.000 & \\
\hline \multirow{2}{*}{ Attitude Towards Learning } & $\mathrm{r}$ & $0.367 * *$ & $0.651 * *$ & $0.675 * *$ & $0.530 * *$ & $0.640 * *$ & 1.000 \\
\hline & $\mathrm{p}$ & 0.000 & 0.000 & 0.000 & 0.000 & 0.000 & 0.000 \\
\hline
\end{tabular}

$*<0.01 ; * *<0.05$

According to the findings in Table 3, it is seen that the subscales of the economic literacy scale are positively related to each other and to the general economic literacy. For example, there is a significant positive correlation between Economic Rationality and Knowledge on Economics ( $r=0.6 ; p=0.000<0.05)$; there is a significant weak positive correlation between Social Economic Reflections and Knowledge on Economics ( $r=0.479, p=0.000$ $<0.05$ ), and there is a significant positive correlation between Economic Literacy General and Knowledge on Economics $(\mathrm{r}=0.86 ; \mathrm{p}=0.000<0.05)$.

There is a weak positive correlation between the Attitude Towards Learning and Knowledge on Economics ( $\mathrm{r}$ $=0.367 ; \mathrm{p}=0.000<0.05$ ), and the lowest correlation value was found at this point. The attitude towards learning is more strongly related to other sub-dimensions of Economic Literacy. For example, there is a significant positive correlation between Economic Rationality ( $\mathrm{r}=0.651, \mathrm{p}=0.000<0.05)$; and there is a significant positive correlation $(\mathrm{r}=0.675 ; \mathrm{p}=0.000<0.05)$ between the Social Economic Reflections. And also, there was a significant positive correlation between the Attitude Towards Learning and Overall Economic Literacy $(r=0.64 ; p=0.000<0.05)$. According to these results, it can be disscussed that there is a significant positive relationship between the attitudes of business owners towards learning and economic literacy.

Table 4. The Effect of Attitudes Towards Learning on Economic Literacy

\begin{tabular}{|c|c|c|c|c|c|c|c|}
\hline Dependent Variable & $\begin{array}{c}\text { Independent } \\
\text { Variable }\end{array}$ & B & $\mathbf{t}$ & $\mathbf{p}$ & $\mathbf{F}$ & $\begin{array}{c}\text { Model } \\
\text { (p) }\end{array}$ & $\mathbf{R}^{2}$ \\
\hline & Constant & 1.264 & 4.392 & 0.000 & 51.132 & 0.000 & 0.132 \\
\hline Knowledge on Economics & $\begin{array}{l}\text { Attitudes } \mathrm{T} \text {. } \\
\text { Learning }\end{array}$ & 0.481 & 7.151 & 0.000 & & & \\
\hline Economic Rationality & Constant & 0.309 & 1.341 & 0.181 & 240.769 & 0.000 & 0.422 \\
\hline
\end{tabular}




\begin{tabular}{|c|c|c|c|c|c|c|c|}
\hline & $\begin{array}{l}\text { Attitudes } \mathrm{T} \text {. } \\
\text { Learning }\end{array}$ & 0.836 & 15.517 & 0.000 & & & \\
\hline \multirow{3}{*}{ Social Economic Reflections } & Constant & 0.817 & 4.249 & 0.000 & 274.140 & 0.000 & 0.454 \\
\hline & $\begin{array}{l}\text { Attitudes T. } \\
\text { Learning }\end{array}$ & 0.743 & 16.557 & 0.000 & & & \\
\hline & Constant & 1.697 & 7.257 & 0.000 & 128.096 & 0.000 & 0.279 \\
\hline Individual Economic Planning & $\begin{array}{l}\text { Attitudes } \mathrm{T} \text {. } \\
\text { Learning }\end{array}$ & 0.618 & 11.318 & 0.000 & & & \\
\hline & Constant & 0.935 & 5.038 & 0.000 & 227.686 & 0.000 & 0.408 \\
\hline General Economic Literacy & $\begin{array}{l}\text { Attitudes T. } \\
\text { Learning }\end{array}$ & 0.654 & 15.089 & 0.000 & & & \\
\hline
\end{tabular}

As seen in the findings of Table 4, the regression analyzes conducted to determine the cause-effect relationship between the Attitude Towards Learning and Economic Knowledge, Economic Rationality, Social Economic Indicators, Individual Economic Planning and Economic Literacy were statistically significant $(\mathrm{F}=51.132$; $\mathrm{F}=240.769 ; \mathrm{F}=274.140 ; \mathrm{F}=128.096$ and $\mathrm{F}=227.686 ; \mathrm{p}=0.000<0.05$ ). It was observed that its relation (explanatory power) to the variables of the Attitudes Towards Learning as a determinant of the level of Economic Information is weak $\left(\mathrm{R}^{2}=0.132\right)$. Business owners' attitudes towards learning increase the level of Knowledge on Economics $(\beta=0.481)$. It was found that its relationship with the Attitude Towards Learning variables as a determinant of the level of Economic Rationality (explanatory power) is very strong $\left(\mathrm{R}^{2}=0.422\right)$. Business owners' attitudes towards learning, increase the level of Economic Rationality $(\beta=0.836)$.

It was observed that its relationship with the variables of Attitude Towards Learning as a determinant of the level of Social Economic Indicators is very strong $\left(\mathrm{R}^{2}=0.454\right)$. Business owners' attitudes towards learning increase the level of Social Economic Indicators $(\beta=0.743)$. It was seen that its relationship with the variables related to learning as a determinant of the level of Individual Economy Planning was also strong $\left(\mathrm{R}^{2}=0.279\right)$. Business owners' attitudes towards learning, increase the level of the Individual Economic Planning $(\beta=0.618)$. It was observed that its relationship with the variables related to learning as a determinant of the level of General Economic Literacy was also strong $\left(\mathrm{R}^{2}=0.408\right)$. Business owners ' attitudes towards learning increase the general level of Economic Literacy $(\beta=0.654)$.

Based on the findings above, it can be said that the attitudes of the business owners towards learning influence the levels of economic literacy. In other words, as the level of attitudes of business owners towards learning increases in the positive direction, this increase can be expected to positively affect the level of economic literacy. The reason for this is that, as emphasized in the above research examples, individuals who are open to learning something constantly can more easily assess their ability to improve their literacy skills.

The Effects of Age, Gender and Marital Status of Business Owners on Economic Literacy and Attitudes Towards Learning

"Does the age, gender and marital status of business owners influence economic literacy and attitudes towards learning?" The analyzes carried out for this question are presented in Tables 5 and 6 . Table 5 shows the results of the analysis based on the age variable.

Table 5. The Comparison of Economic Literacy and Attitudes Towards Learning by The Effect of Age Variable

\begin{tabular}{|c|c|c|c|c|c|c|c|}
\hline $\begin{array}{l}\text { Demographic } \\
\text { Variable }\end{array}$ & $\mathbf{n}$ & $\begin{array}{l}\text { Knowledge } \\
\text { on } \\
\text { Economics }\end{array}$ & $\begin{array}{l}\text { Economic } \\
\text { Rationality }\end{array}$ & $\begin{array}{c}\text { Social } \\
\text { Economic } \\
\text { Reflections }\end{array}$ & $\begin{array}{l}\text { Individual } \\
\text { Economic } \\
\text { Planning }\end{array}$ & $\begin{array}{c}\text { General } \\
\text { Economic } \\
\text { Literacy }\end{array}$ & $\begin{array}{l}\text { Attitude } \\
\text { Towards } \\
\text { Learning }\end{array}$ \\
\hline Age (year) & & Mean \pm SD & Mean \pm SD & Mean \pm SD & Mean \pm SD & Mean \pm SD & Mean \pm SD \\
\hline
\end{tabular}




\begin{tabular}{|c|c|c|c|c|c|c|c|}
\hline $18-25$ & 26 & $\begin{array}{c}2.817 \pm \\
1.103\end{array}$ & $\begin{array}{c}3.551 \pm \\
0.806\end{array}$ & $3.664 \pm 0.711$ & $\begin{array}{c}4.449 \pm \\
0.724\end{array}$ & $3.371 \pm 0.651$ & $\begin{array}{c}4.175 \pm \\
0.649\end{array}$ \\
\hline $26-35$ & 74 & $\begin{array}{c}3.201 \pm \\
0.896\end{array}$ & $\begin{array}{c}3.730 \pm \\
0.897\end{array}$ & $3.627 \pm 0.821$ & $\begin{array}{c}4.000 \pm \\
0.952\end{array}$ & $3.521 \pm 0.732$ & $\begin{array}{c}3.911 \pm \\
0.833\end{array}$ \\
\hline $36-45$ & 123 & $\begin{array}{c}3.338 \pm \\
0.918\end{array}$ & $3.783 \pm 1.023$ & $3.941 \pm 0.857$ & $\begin{array}{c}4.255 \pm \\
0.855\end{array}$ & $3.689 \pm 0.785$ & $\begin{array}{c}4.180 \pm \\
0.760\end{array}$ \\
\hline $46-55$ & 75 & $\begin{array}{c}3.332 \pm \\
0.932\end{array}$ & $\begin{array}{c}4.033 \pm \\
0.881\end{array}$ & $4.257 \pm 0.555$ & $\begin{array}{c}4.511 \pm \\
0.717\end{array}$ & $3.855 \pm 0.659$ & $\begin{array}{c}4.449 \pm \\
0.508\end{array}$ \\
\hline $56-75$ & 32 & $\begin{array}{c}3.637 \pm \\
0.928\end{array}$ & $\begin{array}{c}4.076 \pm \\
0.687\end{array}$ & $4.277 \pm 0.650$ & $\begin{array}{c}4.615 \pm \\
0.634\end{array}$ & $4.001 \pm 0.613$ & $\begin{array}{c}4.587 \pm \\
0.400\end{array}$ \\
\hline $\mathrm{F}=$ & & 3.070 & 2.376 & 8.829 & 5.188 & 4.761 & 8.109 \\
\hline$p=$ & & 0.017 & 0.052 & 0.000 & 0.000 & 0.001 & 0.000 \\
\hline $\begin{array}{l}\text { Advanced } \\
\text { Test (MWU) } \\
=\end{array}$ & & $\begin{array}{l}3>1,4>1, \\
5>1,5>2 \\
(p<0.05)\end{array}$ & & $\begin{array}{c}4>1,5>1, \\
3>2,4>2, \\
5>2,4>3,5>3 \\
(p<0.05)\end{array}$ & $\begin{array}{l}1>2,3>2, \\
4>2,5>2, \\
4>3,5>3 \\
(p<0.05)\end{array}$ & $\begin{array}{l}3>1,4>1, \\
5>1,4>2, \\
5>2,5>3 \\
(p<0.05)\end{array}$ & $\begin{array}{l}5>1,3>2, \\
4>2,5>2, \\
4>3,5>3 \\
(p<0.05)\end{array}$ \\
\hline
\end{tabular}

According to the findings in Table 5, it can be said that with regard to the one-way analysis of variance (ANOVA) which was carried out to determine whether the Knowledge on Economics, Economic Rationality, Social Economic Indicators, Individual Economic Planning, General Economic Literacy and attitudes towards learning score averages of the business owners who participated in the survey showed a significant difference in terms of the age variable, the difference between all group averages except for Economic Rationality subdimension was found to be significant $(\mathrm{F}=3.070 \mathrm{p}=0.017<0.05 ; \mathrm{F}=2.376 \mathrm{p}=0.052 ; \mathrm{F}=8.829 \mathrm{p}=0.000 ; \mathrm{F}=5.188$ $\mathrm{p}=0.000 ; \mathrm{F}=4.761 \mathrm{p}=0.001$ and $\mathrm{F}=8.109 \mathrm{p}=0.000$ ). Hence, the ages of business owners were found to influence economic literacy levels, with the exception of the Economic Rationality sub-dimension. It can be said that as the age increases, the average level of economic literacy increases. In addition, the level of Attitude Towards Learning can change with age. This can be explained with the transition of one's perception from "I know everything" in one's youth to "accepting that there can be much to learn" as he/she matures.

Table 6. The Comparison of The Attitudes Towards Learning and Economic Literacy by The Effects of Gender and marital status variables

\begin{tabular}{lccccccc}
\hline $\begin{array}{l}\text { Demographic } \\
\text { Variable }\end{array}$ & $\mathbf{n} \begin{array}{c}\text { Knowledge on } \\
\text { Economics }\end{array}$ & $\begin{array}{c}\text { Economic } \\
\text { Rationality }\end{array}$ & $\begin{array}{c}\text { The Social } \\
\text { Economic } \\
\text { Reflections }\end{array}$ & $\begin{array}{c}\text { Individual } \\
\text { Economic } \\
\text { Planning }\end{array}$ & $\begin{array}{c}\text { General } \\
\text { Economic } \\
\text { Literacy }\end{array}$ & $\begin{array}{c}\text { Attitude } \\
\text { Towards } \\
\text { Learning }\end{array}$ \\
\hline Gender & 56 & Mean \pm SD & Mean \pm SD & Mean \pm SD & Mean \pm SD & Mean \pm SD & Mean \pm SD \\
\cline { 2 - 7 } Female & 274 & $3.331 \pm 0.932$ & $3.809 \pm 0.944$ & $3.933 \pm 0.802$ & $4.296 \pm 0.853$ & $3.695 \pm 0.751$ & $4.189 \pm 0.733$ \\
Male & & -1.568 & 1.242 & 1.039 & 0.498 & -0.041 & 1.703 \\
$\mathrm{~T}=$ & $\mathbf{0 . 1 1 8}$ & $\mathbf{0 . 2 1 5}$ & $\mathbf{0 . 2 9 9}$ & $\mathbf{0 . 6 1 9}$ & $\mathbf{0 . 9 6 8}$ & $\mathbf{0 . 0 8 9}$ \\
$\mathrm{p}=$ & $\mathrm{Mean} \pm \mathrm{SD}$ & Mean $\pm \mathrm{SD}$ & Mean $\pm \mathrm{SD}$ & Mean $\pm \mathrm{SD}$ & Mean $\pm \mathrm{SD}$ & Mean $\pm \mathrm{SD}$ \\
Marital Status & 251 & $3.310 \pm 0.913$ & $3.863 \pm 0.905$ & $3.998 \pm 0.785$ & $4.317 \pm 0.822$ & $3.719 \pm 0.718$ & $4.242 \pm 0.685$ \\
Married & 79 & $3.243 \pm 1.043$ & $3.758 \pm 0.996$ & $3.812 \pm 0.814$ & $4.270 \pm 0.906$ & $3.615 \pm 0.793$ & $4.149 \pm 0.827$ \\
Single & & 0.544 & 0.879 & 1.819 & 0.436 & 1.096 & 1.000 \\
\hline $\mathrm{t}=$ & & $\mathbf{0 . 5 8 7}$ & $\mathbf{0 . 3 8 0}$ & $\mathbf{0 . 0 7 0}$ & $\mathbf{0 . 6 6 3}$ & $\mathbf{0 . 2 7 4}$ & $\mathbf{0 . 3 1 8}$ \\
$\mathrm{p}=$ & & & & & & &
\end{tabular}

As shown in Table 6, according to the results of analysis of variance with gender and marital status variables, no significant difference between group averages was found ( $\mathrm{p}>0.05)$.

The Effect of The Business Owners' Education Level on The Economic Literacy and The Attitude Towards Learning

"Does the education level of business owners influence economic literacy and attitudes towards learning?" The findings of the analyzes conducted for this question are shown in Table 7.

Table 7. Comparison of Economic Literacy and Learning Attitudes by The Effect of Education Level 
A Study on Attitudes of Business Owners Towards Learning and Economic Literacy

\begin{tabular}{|c|c|c|c|c|c|c|c|}
\hline $\begin{array}{l}\text { Demograph } \\
\text { Variable }\end{array}$ & & $\begin{array}{c}\text { Knowledge on } \\
\text { Economics }\end{array}$ & $\begin{array}{l}\text { Economic } \\
\text { Rationality }\end{array}$ & $\begin{array}{l}\text { The Social } \\
\text { Economic } \\
\text { Reflections } \\
\end{array}$ & $\begin{array}{c}\text { Individual } \\
\text { Economic } \\
\text { Planning } \\
\end{array}$ & $\begin{array}{c}\text { General } \\
\text { Economic } \\
\text { Literacy } \\
\end{array}$ & $\begin{array}{c}\text { Attitude } \\
\text { Towards } \\
\text { Learning } \\
\end{array}$ \\
\hline $\begin{array}{l}\text { Education } \\
\text { Level } \\
\text { n } \\
\end{array}$ & & Mean \pm SD & Mean \pm SD & Mean \pm SD & Mean \pm SD & Mean \pm SD & Mean \pm SD \\
\hline $\begin{array}{l}\text { Primary } \\
\text { School } \\
\text { and Lower }\end{array}$ & 57 & $2.943 \pm 0.876$ & $\begin{array}{c}3.659 \pm \\
0.836\end{array}$ & $3.873 \pm 0.702$ & $\begin{array}{c}4.216 \pm \\
0.813\end{array}$ & $3.480 \pm 0.627$ & $\begin{array}{c}3.977 \mathrm{MI} \pm \\
0.795\end{array}$ \\
\hline $\begin{array}{l}\text { Secondary } \\
\text { School }\end{array}$ & 78 & $3.010 \pm 0.837$ & $\begin{array}{c}3.702 \pm \\
0.868\end{array}$ & $3.689 \pm 0.881$ & $\begin{array}{c}4.350 \pm \\
0.734\end{array}$ & $3.485 \pm 0.683$ & $\begin{array}{c}4.113 \pm \\
0.762\end{array}$ \\
\hline $\begin{array}{l}\text { High } \\
\text { School }\end{array}$ & 109 & $3.343 \pm 0.985$ & $\begin{array}{c}3.886 \pm \\
1.019\end{array}$ & $4.060 \pm 0.776$ & $\begin{array}{c}4.376 \pm \\
0.861\end{array}$ & $3.759 \pm 0.782$ & $\begin{array}{c}4.337 \pm \\
0.669\end{array}$ \\
\hline $\begin{array}{l}\text { Vocational } \\
\text { High } \\
\text { School }\end{array}$ & 10 & $3.346 \pm 0.691$ & $\begin{array}{c}3.489 \pm \\
1.298\end{array}$ & $3.550 \pm 1.195$ & $\begin{array}{c}3.867 \pm \\
1.354\end{array}$ & $3.482 \pm 0.918$ & $\begin{array}{c}4.178 \pm \\
0.895\end{array}$ \\
\hline $\begin{array}{l}\text { Associate's } \\
\text { degree }\end{array}$ & 28 & $3.420 \pm 0.794$ & $\begin{array}{c}3.893 \pm \\
0.813\end{array}$ & $4.071 \pm 0.624$ & $\begin{array}{c}4.262 \pm \\
0.624\end{array}$ & $3.784 \pm 0.581$ & $\begin{array}{c}4.270 \pm \\
0.575\end{array}$ \\
\hline $\begin{array}{l}\text { Bachelor's } \\
\text { degree and } \\
\text { higher }\end{array}$ & 48 & $3.976 \pm 0.853$ & $\begin{array}{c}4.204 \pm \\
0.787\end{array}$ & $4.250 \pm 0.630$ & $\begin{array}{c}4.299 \pm \\
0.971\end{array}$ & $4.134 \pm 0.677$ & $\begin{array}{c}4.396 \pm \\
0.641\end{array}$ \\
\hline $\mathrm{F}=$ & & 9.162 & 2.682 & 4.429 & 0.884 & 6.567 & 2.908 \\
\hline $\mathrm{p}=$ & & 0.000 & 0.022 & 0.001 & 0.492 & 0.000 & 0.014 \\
\hline $\begin{array}{l}\text { Advanced } \\
\text { Test } \\
(\mathrm{MWU})=\end{array}$ & & $\begin{array}{c}3>1,5>1,6>1, \\
3>2,5>2,6>2, \\
6>3,6>4,6>5 \\
(p<0.05)\end{array}$ & $\begin{array}{l}6>1,6>2, \\
6>3,6>4 \\
(p<0.05)\end{array}$ & $\begin{array}{l}6>1,3>2, \\
5>2,6>2, \\
3>4,6>4 \\
(p<0.05)\end{array}$ & & $\begin{array}{c}3>1,6>1, \\
3>2,6>2, \\
6>3,6>4, \\
6>5(p<0.05)\end{array}$ & $\begin{array}{l}3>1,6>1, \\
3>2,6>2 \\
(p<0.05)\end{array}$ \\
\hline
\end{tabular}

According to the results of the analysis given in Table 7 with regard to the one-way analysis of variance (ANOVA) which was done to determine whether the Economic Information, Economic Rationality, Social Economic Indicators, Individual Economic Planning, General Economic Literacy and Attitudes Towards Learning score averages of the business owners who participated in the survey showed a significant difference in terms of the educational background and the difference between all group averages were found to be significant $(\mathrm{F}=9.162$; $\mathrm{F}=2.682 ; \mathrm{F}=4.429 ; \mathrm{F}=6.567$ and $\mathrm{F}=2.908 \mathrm{p}<0.05)$. However, the difference between the averages of the "Individual Economic Planning" scores of the business owners was not found to be significant in terms of the education variable $(\mathrm{F}=0.884, \mathrm{p}=0.492>0.05)$.

The difference between the mean of the groups was found to be significant $(\mathrm{F}=2.908 ; \mathrm{p}=0.014<0.05)$ according to the results of ANOVA conducted to determine whether the average of the attitude towards learning scores of the business owners participating in the study showed a significant difference in terms of educational background variable. The PostHoc test was used to determine which group originated the difference. According to this, it was found that: The attitude towards learning score of those with the education level of high school (4.337 \pm 0.669$)$ is higher than those with a primary school or lower education status $(3.977 \pm 0.795)$. The attitude towards learning score of those with a bachelor's degree or higher $(4.396 \pm 0.641)$ is higher than those with a primary school or lower educational status $(3.977 \pm 0.795)$. The attitude towards learning score of those with a high school educational status $(4.337 \pm 0.669)$ is higher than those with a secondary school educational status $(4.113 \pm 0.762)$. The attitude towards learning score of those with a bachelor's degree or higher (4.396 \pm 0.641$)$ is higher than those with a secondary school educational status $(4.113 \pm 0.762)$.

Based on these findings, it can be disscussed that the other sub-dimensions of Economic Literacy and General Economic Literacy levels and Attitudes Towards Learning, except for the Individual Economy Planning subdimension, may change with the level of education of the business owners. In other words, as the level of education of business owners increases, the averages of both economic literacy and attitudes towards learning can increase. This is in accordance with the knowledge-based characteristic of the economic literacy. The fact that attitude scores on learning can change with education level is parallel to the findings obtained from various national and international research. Increasing the level of education of individuals can help people understand the value of the learning products and therefore contributing to the approaches and trends of learning to change positively. 
The Effects of Monthly Income Level and Duration of Work Experience on The Economic Literacy and The Attitude Towards Learning

"Does the level of income of business owners influence the economic literacy and the attitude towards learning?" and "Does the duration of work experience of business owners influence the economic literacy and the attitude towards learning?" about these research questions, the following findings of the analyzes were obtained.

According to the results of the one-way analysis of variance (ANOVA) which was done to determine whether the business owners' average scores of Knowledge on Economics in terms of income variable score average, the difference between group averages was found to be significant $(\mathrm{F}=2.436 ; \mathrm{p}=0.047<0.05)$. Thus, as the monthly income of business owners increases, the level of economic knowledge can change as well. This can be explained by the need for more information in the process of using an increasing income on financial markets. However, there was no significant difference between the groups in terms of income level of the average scores of the business owners' Economic Rationality, Social Economic Indicators, Individual Economy Planning, General Economic Literacy and Attitudes Towards Learning ( $p>0.05)$. Table 8 shows the findings regarding the duration of experience in the economic activity carried out by the participants.

Table 8. Comparison of Economic Literacy and Learning Attitudes by The Effect of Job Experience

\begin{tabular}{|c|c|c|c|c|c|c|c|}
\hline $\begin{array}{l}\text { Demographic } \\
\text { Variables }\end{array}$ & $\mathbf{n}$ & $\begin{array}{c}\text { Knowledge } \\
\text { on } \\
\text { Economics }\end{array}$ & $\begin{array}{l}\text { Economic } \\
\text { Rationality }\end{array}$ & $\begin{array}{l}\text { The Social } \\
\text { Economic } \\
\text { Reflections }\end{array}$ & $\begin{array}{l}\text { Individual } \\
\text { Economic } \\
\text { Planning }\end{array}$ & $\begin{array}{l}\text { General } \\
\text { Economic } \\
\text { Literacy }\end{array}$ & $\begin{array}{l}\text { Attitude } \\
\text { Towards } \\
\text { Learning }\end{array}$ \\
\hline $\begin{array}{l}\text { Experience } \\
\text { (year) }\end{array}$ & & Mean \pm SD & Mean \pm SD & Mean \pm SD & Mean \pm SD & Mean \pm SD & $\begin{array}{c}\text { Mean } \pm \\
\text { SD }\end{array}$ \\
\hline $0-5$ & 85 & $3.063 \pm 0.931$ & $\begin{array}{c}3.492 \pm \\
0.949\end{array}$ & $3.544 \pm 0.802$ & $\begin{array}{c}4.059 \pm \\
0.896\end{array}$ & $3.387 \pm 0.744$ & $\begin{array}{c}3.873 \pm \\
0.831\end{array}$ \\
\hline $6-10$ & 74 & $3.258 \pm 0.904$ & $\begin{array}{c}3.814 \pm \\
0.878\end{array}$ & $3.907 \pm 0.739$ & $\begin{array}{c}4.284 \pm \\
0.833\end{array}$ & $3.660 \pm 0.675$ & $\begin{array}{c}4.177 \pm \\
0.721\end{array}$ \\
\hline $11-15$ & 71 & $3.091 \pm 1.026$ & $\begin{array}{c}3.776 \pm \\
1.059\end{array}$ & $4.018 \pm 0.825$ & $4.380 \pm 0.895$ & $3.620 \pm 0.820$ & $\begin{array}{c}4.352 \pm \\
0.679\end{array}$ \\
\hline $16-20$ & 41 & $3.443 \pm 0.859$ & $\begin{array}{c}4.108 \pm \\
0.766\end{array}$ & $4.162 \pm 0.750$ & $\begin{array}{c}4.382 \pm \\
0.780\end{array}$ & $3.884 \pm 0.614$ & $\begin{array}{c}4.396 \pm \\
0.509\end{array}$ \\
\hline $21-25$ & 24 & $3.872 \pm 0.774$ & $\begin{array}{c}4.037 \pm \\
0.806\end{array}$ & $4.349 \pm 0.626$ & $\begin{array}{c}4.500 \pm \\
0.637\end{array}$ & $4.090 \pm 0.609$ & $\begin{array}{c}4.482 \pm \\
0.513\end{array}$ \\
\hline $\begin{array}{l}25 \text { years and } \\
\text { above }\end{array}$ & 35 & $3.771 \pm 0.762$ & $\begin{array}{c}4.403 \pm \\
0.495\end{array}$ & $4.396 \pm 0.471$ & $4.581 \pm 0.683$ & $4.169 \pm 0.438$ & $\begin{array}{c}4.498 \pm \\
0.524\end{array}$ \\
\hline $\mathrm{F}=$ & & 5.885 & 6.465 & 9.720 & 2.727 & 8.917 & 7.247 \\
\hline $\mathrm{p}=$ & & 0.000 & 0.000 & 0.000 & 0.020 & 0.000 & 0.000 \\
\hline $\begin{array}{l}\text { Advanced } \\
\text { Test (MWU) } \\
=\end{array}$ & & $\begin{array}{l}4>1,5>1, \\
6>1,5>2, \\
6>2,4>3, \\
5>3,6>3 \\
(p<0.05)\end{array}$ & $\begin{array}{c}2>1,3>1, \\
4>1,5>1, \\
6>1,6>2, \\
6>3(p<0.05)\end{array}$ & $\begin{array}{l}2>1,3>1, \\
4>1,5>1, \\
6>1,5>2, \\
6>2,6>3 \\
(p<0.05)\end{array}$ & $\begin{array}{l}3>1,4>1, \\
5>1,6>1 \\
(p<0.05)\end{array}$ & $\begin{array}{c}2>1,3>1, \\
4>1,5>1, \\
6>1,5>2, \\
6>2,5>3,6>3 \\
(p<0.05)\end{array}$ & $\begin{array}{l}2>1,3>1, \\
4>1,5>1, \\
6>1,6>2 \\
(p<0.05)\end{array}$ \\
\hline
\end{tabular}

In the light of the findings in table 8 , the following observations can be made: The difference between the average scores of all sub-dimensions and the general level of Economic Literacy is found to be significant in terms of the duration of experience variables of business owners participating in the survey. In addition, the average Attitude Towards Learning scores of the business owners showed a significant difference in terms of experience variables $(\mathrm{F}=7.247, \mathrm{p}=0.000<0.05)$. The results of this analysis showed that business owners' both attitudes towards learning and economic literacy levels can increase as duration of work experience increases. Such a result is a confirmation of the basic justifications of the lifelong learning philosophy. Because by being more open and willing to learn, business owners as adult individuals, have the opportunity to increase their economic literacy competencies as their experience in work increases.

\section{Discussion and Conclusion}


According to the findings of this survey presented above, it is seen that research problems are mainly answered positively. It was observed that the economic literacy of the business owners is influenced by the attiudes towards learning and the positive learning attitude may increase the economic literacy. In addition, participants' attitude scores for learning were higher than the average of economic literacy scores. This is an indicator of a mass that is open to learning.

It was determined that the age of the business owners, the level of education and the duration of their own experience at work may also have an effect on economic literacy and attitudes towards learning. In other words, individuals' attitudes toward learning and the level of economic literacy may increase as the age, the education and the work experience increase, or vice versa. This situation can be defined by age-related maturation, as well as by realizing the fact that the knowledge and skills required by today's globalization process.

The point that needs to be emphasized is that all literacy competencies that can be acquired through processes outside the formal education system, such as economic literacy is related to the individuals' approach to learning. Because it is the society that pays the price, at a socio-economic and political level, of those who are close-minded towards learning and life-long development. In fact, it should not be forgotten that individuals who have undertaken an economic role by demonstrating courageous entrepreneurship have social obligations at a critical level as well as the individual risk they are taking.

Studies on economic education for adults should be programmed by taking into account the disadvantaged segments such as women and immigrants who have been deprived of high school education and the further stages of formal education, as stated in the work of Kim (2012). Because the political preferences and attitudes of low educated individuals (lay learners) towards economic politics can actually be against their own socio-economic interests. Due to their role in production and employment contribution, business owners are also in the segments that must be taken into account during the formation of the education programs on economic literacy.

The attitudes of business owners (entrepreneurs) towards learning who have a key role in the development of Turkey's economy and new research proposals on economic literacy can be summarized as follows:

- An inventory of the learning needs of all entrepreneurs or business owners can be prepared on the basis of provinces via the Chambers of Commerce and Industry and Turkish Employment Agency. Such inventories which should be conducted through surveys will form the basis of the curricula of educational programs for all types of literacy.

-Through the projects at the level of neighborhoods or municipalities, the exchange of knowledge and skill profiles can be monitored by applying the periodic analyzes to the managers and staff of the workplaces. In these profiles, public education models may be designed to encourage individuals who are more educated and more experienced to teach the economic information they learned to people in different workplaces. 


\title{
İSYERI SAHIPLERININ ÖĞRENMEYE İLIŞKIN TUTUMLARI İLE EKONOMI OKURYAZARLIĞI DÜZEYLERI ÜZERINE BİR INCELEME: MERSIN ÖRNEĞI
}

\begin{abstract}
Giriş
Ekonomik yaşamın yüksek devingenliğinin etkilerine en çok maruz kalan kesim, hiç şüphesiz ki bir işyerini işletmekte olan işyeri sahipleridir. Bu toplumsal kesim, günümüz ekonomilerindeki yapının en kritik işlevlerini yüklenmiş durumdadır. Çünkü, bir ekonomik faaliyeti kurma ve/veya tüm maliyetleri ve yükümlülükleriyle sürdürebilme becerisinin, sosyo-ekonomik dengelerin korunabilmesine katkı yaptığını savunmak yanlış olmayacaktır.

Küçük veya orta ölçekli bir şirket ya da esnaflık olsun, bir işyerinin işletilmesinden ve yönetiminden sorumlu olmak, bazı teknik bilgi ve becerilere de sahip olmayı gerektirir. Bu nedenle bir öğrenci, devlet memuru veya ev hanımı gibi toplumun diğer kesimlerinden bireylere kıyasla, bir işyeri açmış ve işletmekte olan bireylerin sahip olması gereken farklı yeterlikler ve beceriler karşımıza çıkar. Bu tür bilgi ve becerilerin tümünün örgün eğitim sistemleriyle kazandırılmasının mümkün olmaması, yaşamboyu öğrenme felsefesinin güncel olguları konumundaki çeşitli okuryazarlık türlerinin önem kazanmasını sağlamıştır. Bunlardan biri olan ekonomi okuryazarlığı ise, her boyutuyla kritik bir işlevselliğe sahiptir.

Bununla birlikte, böylesi bir işlevselliğin somutlaşabilmesinin, bireyin ihtiyaç duyduğu bilgi ve becerileri algılayarak, gereken öğrenme etkinliklerine yönelebilmesine bağlı olduğu ileri sürülebilir. Dolayısıyla, ekonomi okuryazarlığının tek başına yeterli bir ölçüt veya hedef sayılamayacağı, bu nedenle bir işyeri sahibinin öğrenmeye ve öğrenerek kişisel gelişimi başarabilmeye ilişkin olumlu bir bakış açısını da taşıması gerektiği savunulabilir. Bu nedenle, bireylerin öğrenme etkinliklerine olan ilgi ve eğilimlerini ifade eden öğrenmeye yönelik tutumun, ekonomi okuryazarlığına olumlu veya olumsuz etkileri olabilecektir. Çünkü, toplumdaki farklı meslek gruplarının veya kesimlerin ihtiyaç duyduğu bilgi, beceri ve yeterliklerin kazandırılabilmesi, öğrenmeye yönelik olumlu tutumların varlığına bağlıdır. Son olarak, ilgili alanyazında, işyeri sahiplerinin öğrenmeye ilişkin tutumlarına ve ekonomi okuryazarlığına dönük bir araştırmaya rastlanmamıştır. Bu bağlamda, bu araştırmanın disiplinlerarası düzeyde bir ihtiyacı karşılayarak, farklı meslek gruplarından bireyler için farklı okuryazarlık türlerine ilişkin eğitim programı geliştirme süreçlerine katkı yapabileceği düşünülmektedir.

Bu çalışmanın amacı, bir ekonomik faaliyeti sürdürmekte olan işyeri sahiplerinin bazı demografik özelliklerine göre öğrenmeye yönelik tutumları ile ekonomi okuryazarlığı etkileşiminin ve bunlardaki değişimin belirlenmesidir. Çalışmanın araştırma soruları ise şöyledir:

- İşyeri sahiplerinin öğrenmeye yönelik tutumlarının, ekonomi okuryazarlıklarına etkisi var mıdır?

- İşyeri sahiplerinin yaş, cinsiyet ve medeni durumlarının, ekonomi okuryazarlıklarına ve öğrenmeye yönelik tutumlarına etkisi var mıdır? var midir?

- İşyeri sahiplerinin eğitim düzeyinin, ekonomi okuryazarlıklarına ve öğrenmeye yönelik tutumlarına etkisi

- İşyeri sahiplerinin aylık gelir düzeyinin, ekonomi okuryazarlıklarına ve öğrenmeye yönelik tutumlarına etkisi var midır? var midir?

- İşyeri sahiplerinin iş deneyimi süresinin, ekonomi okuryazarlıklarına ve öğrenmeye yönelik tutuma etkisi
\end{abstract}

\section{Ekonomi Okuryazarlığı}

Dünya genelindeki ekonomik gelişmeler ve finansal serbestleşme sonucunda, bireylerin finansal sisteme daha fazla entegre olmaları ve karmaşıklaşan ekonomik karar alma süreçleri, bireylerin bu konularda ihtiyaç duyabilecekleri bilgi ve becerileri daha önemli hale getirmiştir. Bu bağlamda ekonomi okuryazarlı̆̆ , gerek piyasaların gerekse de ülke ve dünya ekonomisinin gelişimi ve etkinliği açısından oldukça önemli bir yere sahiptir (Ergün vd., 2014:848). Bununla birlikte, bu derece kritik roller yüklenebilen ekonomik bilgi ve becerilerin, farklı toplumsal kesimler tarafından yeterince kazanılamadığı ve hatta bireylerin bu konudaki bilgisizliğinin istismar edilebildiği söylenebilmektedir. Bu duruma en iyi örneklerden birisi, Kim (2012: 194-195)'in düşük eğitimli yetişkinlere dönük araştırmasıdır. Bu çalışmada, uygun yöntemlerin kullanıldığı ekonomi okuryazarlığı öğretimi sonucunda, çok düşük eğitime sahip yetişkinlerin dahi bilinçlenerek kendi sosyo-ekonomik konumlarına uygun ekonomik ve politik kararlar almayı başarabildiği görülmüştür. Bu tür bulgular, hem ekonomi okuryazarlığının işlevselliğini hem de geniş kapsamının etkilerini vurgular niteliktedir. 
Ekonomi okuryazarlığı olgusu, toplumun her kesiminden bireyi etkiler. Elindeki sınırlı kaynaklar ile maksimum fayda temin etmek isteyen bireylerin, belirli düzeyde ekonomi okuryazarı olması beklenir. Bu gereklilik, finansal piyasalarda ve toplumun demografik yapısında meydana gelen değişimlerle daha da belirginleşmektedir. Üstelik, finansal araçların giderek çeşitleniyor olması da ekonomi okuryazarlığının önemini artırmıştır. (Kahya ve İmamoğlu, 2015:142). Ekonomi okuryazarlığı kavramı, değişik disiplinlerde farklı şekillerde tanımlanmakta ayrıca çoğu zaman finansal okuryazarlık kavramıyla da aynı anlamda kullanılmaktadır. Bazı tanımlarda ekonomi okuryazarlığı, kişilerin ekonomiyle ilgili bilgi düzeylerini ifade ederken, bazı tanımlarda daha kapsamlı bir şekilde ele alınmakta ve ekonomi bilgisi yanında beceriler de göz önünde bulundurulmaktadır (Şantaş ve Demirgil, 2015:47).

Literatürde ekonomi okuryazarlığı kavramının bir çok farklı tanımı bulunmakla birlikte en geniş tanımlardan biri, North Central Regional Educational Laboratory (2003), tarafından yapılmıştır. Bu tanıma göre; ekonomi okuryazarlığı, "ekonomide meydana gelen problemleri ve ortaya çıkan üstünlükleri tespit edebilme, ekonomideki koşullarda ve kamu politikalarında meydana gelen değişimleri takip edebilme, ekonomik verileri toplayabilme ve organize edebilme, finansal olayların fayda-maliyet boyutunu göz önünde bulundurabilme yeteneği”dir (NCREL, 2003:20; Ünal vd., 2015:34). Burkhardt vd. (2003), ekonomi okuryazarlı̆̆ kavramını, ekonomi kaynaklı problemleri, alternatifleri, fiyatları ve yararlarını tanımlama, işyerindeki teşvikleri analiz etme, yerel politikalardaki değişimlerin sonuçlarını değerlendirme, ekonomik kanıtlar toplama, organize etme ve getirilere karşılık tutarı ölçebilme yeteneği olarak tanımlamıştır (Akt. Akhan, 2013:4). Ekonomik gelişmeleri ve bu gelişmelerin işsizlik, bireysel harcamalar, finansal etkinlikler gibi farklı alanlardaki etkilerini yorumlayabilme becerisi olarak da tanımlanan ekonomi okuryazarlığ

- Üretici, tüketici ve yatırımcı olarak kar ve maliyet ile kaynakların sınırlılığını değerlendirerek daha bilinçli seçimler yapabilme

- Her bir yöntemin kar ve zararını tartarak hizmetleri ve kazançları ayırarak değerlendirebilme

- Bireylerin davranışlarını etkileyen ekonomik güdüleri tanımlayabilme

- Rekabetin, ticari engellerin, kıtlık ve aşırılık ile üretici tüketici arasındaki etkileşimin fiyatlara nasıl yansıdığını anlayabilme

- Kamu ve özel ekonomi kurumlarının rollerini tanımlayabilme

- Gelirin temelleri ile dağılımının yanı sıra risk, yatırım, işsizlik, enflasyon, faiz oranlarını anlayabilme

- Alternatif kamu politikalarının fayda ve zararlarını değerlendirerek tanımlayabilme

- Girişimciliğin değerini ve ekonomideki küçük ve büyük ölçekli işletmelerin rollerini anlayabilme (NCREL, 2003:20; Gerek ve Kurt, 2011:59-61).

Ekonomi okuryazarlığı ile ilgili çalışmalar incelendiğinde; Jappelli (2010: 435-440)'nin 55 ülkeyi kapsayan çalışması dikkat çeker. Bu uluslararası çalışmada, bireylerin ekonomi okuryazarlığı düzeyinin düşük olduğu ve temel ekonomik kavramlara dahi ilgi duyulmadığı görülmüştür. Karşılaştırmalı analizleri içeren bu araştırmanın bulguları, ekonomi okuryazarlığının, kişi başına düşen milli gelir düzeyiyle bağlantılı olduğunu ve bireylerin ekonomi okuryazarlığının, sosyal güvenlik sistemlerinin güçlendirilmesiyle geliştirilebileceğini göstermiştir. Bu durum çeşitli ülkelerde yapılan PISA testi sonuçlarıyla da pareleldir (Jappelli, 2010:430,435). Schug ve Hagedorn'un (2005) çalışması, ilköğretim düzeyinde ekonomi ile ilgili eğitim programlarının, harcama ve biriktirme gibi temel ekonomik konularda olumlu etkisi olduğunu göstermiştir. Mercan vd.'nin (2012: 112,117) Türkiye Ulaştırma Bakanlığı'nın bir şubesinde çalışan 93 kişinin ekonomi okuryazarlığını ölçmeye çalışan çalışmalarında, özellikle eğitim düzeyi ile ekonomi okuryazarlığı arasında anlamlı sonuçlar elde edilmiştir. Ankete katılan deneklerin 85'i üniversite veya yüksek lisans mezunudur. Ankete katılan çalışanların bireysel ekonomi kullanımı boyutunda yüksek düzeyde ekonomi okuryazarı oldukları ortaya çıkmıştır. Şantaş ve Demirgil (2015: 57-58), bir devlet üniversitesinin İktisadi ve İdari Bilimler Fakültesi'nde öğrenim gören birinci ve dördüncü sınıf öğrencilerin ekonomi okuryazarlık düzeyinin saptanması amacıyla yaptıkları çalışmada, yaşları 22 ve üzerinde olan iktisat ve maliye bölümlerinde öğrenim gören, ekonomik ve finansal gelişmeleri her gün takip eden erkek öğrencilerin daha yüksek ekonomi okuryazarlığı algısına sahip olduğu saptanmıştır.

\section{Öğrenmeye Yönelik Tutum}

Öğrenme, en yaygın tanımıyla, bireyin çevresiyle etkileşimi sonucunda doğan kalıcı davranış değişimleridir. $\mathrm{Bu}$ davranış değişimlerinin niteliği ve işlevselliği, beraberinde değişimi ve gelişimi getirecektir (Senemoğlu, 2009:3-4). Böylesi bir sonuç ise, bireyin tutumlarına bağlıdır. Tutum, bir kişinin, çevresindeki dünyaya karş1 geliştirdiği olumlu veya olumsuz değerlendirmelerden oluşan psikolojik eğilimleri ifade eder (Chang ve Chang, 
2013:458). Başka bir tanıma göre tutum, kişilerin düşüncelerini ve davranışlarını etkileyen zihinsel ve duygusal durumdur (Shih ve diğerleri, 2011:376). Bu tanımdan hareketle, öğrenmeye yönelik tutum veya öğrenme tutumu ise, bireylerin, öğrenme etkinliklerine yönelik eğilimleri olarak nitelendirilebilir.

Yetişkin bireylerin, günlük toplumsal yaşamın akışı içerisinde karşılaşılan sorunları çözebilmesi ve her deneyimle birlikte değişerek gelişebilmeyi başarabilmesi, öğrenmeye dönük olumlu duygu ve düşüncelere sahip olmasına bağlıdır. Nitekim, bireylerin öğrenmeye ilişkin yaklaşımlarının, öğrenme ürünlerini ve başarı düzeyini etkilediğini gösteren çeşitli araştırma bulguları mevcuttur. Buna göre, öğrenmeye daha açık olan ve öğrenmeye ilişkin kaygı düzeyi düşük olan bireylerin başarı ve gelişim düzeylerinin, diğerlerine kıyasla daha yüksek olduğu söylenebilir (Kara, 2010:50-51; Aydın, 2016:76). Hsu'ya göre, öğrenme tutumu, bireyin tüm öğrenme etkinliklerinde belirleyicidir. Dolayısıyla, bir öğrencinin öğrenme etkinliklerinde yer alan öğretmen ve öğrenme materyalleri gibi tüm kişi, olay ve nesnelere karşı tutumu, onun öğrenme davranışları ile öğrenme sürecindeki başarısını da etkileyebilir. Bu nedenle öğrenme tutumunun bilişsel (kişinin çevresindeki şeylerle ilgili inançları veya bilgileri), duyuşsal (sempati, hoşlanma gibi duyguları) ve davranışsal bileşenleri (öğrenmeyle ilgili eylemleri yapma veya reddetme) bulunmaktadır (Akt. Chang ve Chang, 2013:458-459). Bu bağlamda, bir öğrenci, öğrenmeye gerçekten ilgi duyduğunda öğrenme ve anlama etkinliklerine katılmaya yönelik aktif ve etkin bir tutum sergileyebilir (Chang ve Chang, 2013:459). Nitekim, Chang ve Chang'ın (2013:462) araştırmasında da, öğrenmeye yönelik motivasyon ile öğrenme tutumu arasında yüksek korelasyon bulunmuştur.

Hedef kitleleri öğrenciler ile öğretmenlerden oluşan bazı araştırmaların bulguları göstermiştir ki, bilgisayar ve internet temelli öğrenme etkinliklerine karşı evrensel düzeyde geçerliliği olan bir tutum yoktur. Fakat, böyle bir tutumun duyuşsal, bilişsel ve davranışsal boyutları bulunmaktadır (Liaw ve diğerleri, 2007: 1069). Öğretmenlerin öğrenme tutumuna dönük son araştırmalar ise, çoğunlukla bilgisayar ve internet kullanımını temel almıştır. Örneğin, Kao ve Tsai'nin (2009:72) araştırması, öğretmenlerin bilgisayar ve internet kullanarak öğrenme ve öğretmeye yönelik tutumlarını etkileyen psikolojik etkenleri incelemiştir. Aktürk'ün (2012:291-292) öğretmen adaylarının öğrenmeye ilişkin tutumlarını mesleği tercih nedenlerine ve akademik başarıya göre incelediği araştırmasının sonuçlarına göre, içsel nedenlerle (idealistlik gibi nedenler) öğretmenlik mesleğini tercih etmiş olanların öğrenmeye yönelik tutumu, çevresel etkenlerle mesleğe yönelmiş olanlara kıyasla çok daha olumlu ve öğrenmeye yönelik kaygıları ise daha düşük bulunmuştur. Aydın'ın (2016:81) yine öğretmen adaylarına dönük araştırmasında ise, fen bilgisi öğretmen adaylarının öğrenmeye ilişkin tutum düzeylerinin yüksek ve olumlu yönde olduğu saptanmış olup, kadın öğretmen adayları öğrenmeye daha açık iken, erkek öğretmen adaylarının öğrenmeye ilişkin kaygı düzeyleri daha düşük çıkmıştır.

Sonuç olarak, ilgili alanyazınlar tarandığında öğrencilerin, öğretmen adaylarının, öğretmenlerin ve akademisyenlerin öğrenmeye ilişkin tutumlarını inceleyen birçok araştırmanın bulunduğu, buna karşılık işyerlerine veya işyeri sahiplerine dönük bir çalışmanın bulunmadığı görülmüştür.

\section{Öğrenmeye Yönelik Tutumun Ekonomi Okuryazarlığıyla Etkileşimi}

Örgün eğitim kapsamındaki öğrenme ve eğitim çalışmalarını inceleyen araştırmaların gösterdiği üzere, öğrenmeye ilişkin olumlu tutum sergileyen bireylerin öğrenme etkinliklerinden elde edeceği sonuçlar daha verimli

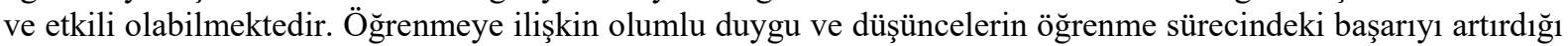
gerçeğinden yola çıkarak, öğrenmeye yönelik olumlu tutum sergileyen bireylerin, çeşitli okuryazarlık türlerinin kazanılmasında da başarılı olması beklenir. Bu nedenle, öğrenmeye yönelik tutum ile ekonomi okuryazarlığı arasında pozitif bir korelasyon olması olasıdır. Böyle bir ilişkinin varlığı ve düzeyi, çeşitli okuryazarlık yeterlikleriyle bağlantılı olarak yetişkin öğrenmesi ve yetişkin eğitimi çalışmaları için olumlu bir rol oynayacaktır.

Önemi artmakta olan ekonomi okuryazarlığı olgusunun toplumdaki etkinliğini artırabilmek için ihtiyaçlara uygun yaygın eğitim programlarının geliştirilmesi şarttır. Bu tür eğitim programlarının geliştirilebilmesinin ön koşulu ise eğitim ihtiyaçlarının belirlenmesidir. İhtiyaçlar toplumun farklı kesimlerinde değişik biçimlerde ortaya çıkabilmektedir (Temizel ve Bayram, 2011:74). Örneğin, üniversite öğrencilerinin ekonomi okuryazarlı̆̆ çerçevesinde ihtiyaç duyacağı bilgi ve beceriler ile bir işyerini çalıştırmakta olan işyeri sahiplerinin ihtiyaç duyabileceği bilgi ve beceriler de farklılık sergileyebilecektir. Fakat, güncel bilgi ve becerileri elde edebilmek için öncelikle öğrenmeye karşı olumlu bir tutum içerisinde olmak gerekir. Dolayısıyla, Türkiye'de yaşayan ve bağımsız olarak kendi hesabına bir işyeri işleten bir işyeri sahibinin ekonomi okuryazarlığı düzeyinin, hem öğrenme ihtiyaçları algısı hem de öğrenmeye ilişkin tutumuyla bağlantılı olması olasıdır.

\section{Yöntem}


Bu başlık altında, araştırmanın evren ve örneklem büyüklüğü, veri toplama aracı ve verilerin analizine ilişkin bilgiler sunulmuştur. Bu kapsamda, öncelikle araştırma deseni hakkında bilgiler verilmiş olup, daha sonra evren ve örneklem, veri toplama aracı ve verilerin analiziyle ilgili bilgiler aktarılmıştır.

\section{Araștırma Modeli}

Bir araştırma modelinin tanıtılması sürecinde, değişkenlerin ve kullanılan tekniklerin tanımlanması, araştırma kapsamının ortaya konulmasına ilişkin temel bilgileri sağlar. Bu çalışmadaki araştırma sorularının yapısı ve araştırmanın amacı, nicel analiz tekniklerinin kullanılmasını gerekli kılmıştır. Nicel araştırmaların büyük bölümünü, kullanılan teknikler açısından iki grupta sınıflandırmak mümkündür: Betimsel araştırmalar ve nedensel karşılaş̧ırma araştırmaları (Balcı, 2010:218). Bu nicel çalışmanın amacına ve araştırma sorularına dayanılarak hem betimsel hem de nedensel karşılaş̧ırmayı kapsadığı söylenebilir. Çalışmanın amacına ve araştırma sorularına paralel olarak, araştırmanın esas bağımlı değişkeni, işyeri sahiplerinin ekonomi okuryazarlı̆̆ıdır. Bununla birlikte, işyeri sahiplerinin ekonomi okuryazarlığı ve öğrenmeye ilişkin tutumları, bazı demografik bağımsız değiş̧kenlerin etkisine göre hem bağımlı hem de bağımsız değişken niteliği kazanmıştır. Bu nedenle, ilişkisel analiz için gerekli olan korelasyon ve regresyon tekniklerinin de kullanılması gerekmiştir.

\section{Evren ve Örneklem}

Çalışmanın evreni, Mersin ilinde faaliyet göstermekte olan esnaflar, mağazalar veya şirket ofisleri olarak sınıflandırılabilecek işyerlerinin sahipleridir. Bu kapsamda, Mersin il merkezinde faal olan işyeri sayısının 50.630 olması nedeniyle (TESK, 2017), örneklem büyüklüğü olarak \%95 güven aralığında 381 değeri belirlenmiştir (Altunışık vd., 2010:135). Fakat, 385 adet form çoğaltılarak dört anketör ve iki araştırmacıyla birlikte yürütülmüş olan anket uygulanması sonucunda, saha araştırmalarında rastlanan yaygın sorunlar nedeniyle değerlendirmeye alınabilecek düzeyde olduğu kabul edilen anket formu sayısı 330'da kalmış ve çalışma grubu büyüklüğü 330 olmuştur. Çalışma grubunu oluşturan katılımcılar, tesadüfi örneklem yöntemiyle belirlenmiştir.

Örneklemi oluşturan katılımcıların özellikleri. Rastgele seçilmiş katılımcıların oluşturduğu çalışma grubu, 330 işyeri sahibinden oluşmaktadır. Bu kısımda, ilk olarak, bu işyeri sahiplerinin iş türü, yaş, cinsiyet, eğitim düzeyi, medeni hal, aylık gelir düzeyi ve işteki deneyim süresi değişkenlerine yer verilmiş̧ir. İkinci aşamada, katılımcıların öğrenmeye ilişkin tutum ile ekonomi okuryazarlığı düzeyleri sunulmuştur.

Tablo 1, araştırmanın amacı ve araştırma sorularıyla bağlantılı olarak, katılımcılara ilişkin bazı demografik verileri göstermektedir. Katılımcıların yaş, cinsiyet, eğitim düzeyi, medeni hal, aylık gelir düzeyi ve ekonomik faaliyetlerindeki deneyim sürelerine ilişkin durumları, demografik bir profil sunabilmek amacıyla gösterilmiştir.

Tablo 1. İşyeri Sahiplerinin Bazı Demografik Özelliklerinin Dağılımı

\begin{tabular}{|c|c|c|c|}
\hline Değișken & Gruplar & Frekans (f) & Yüzde (\%) \\
\hline \multirow{7}{*}{ Yaş } & $18-25$ & 26 & 7.9 \\
\hline & $26-35$ & 74 & 22.4 \\
\hline & $36-45$ & 123 & 37.3 \\
\hline & $46-55$ & 75 & 22.7 \\
\hline & $56-65$ & 23 & 7 \\
\hline & $66-75$ & 9 & 2.7 \\
\hline & Toplam & 330 & 100 \\
\hline \multirow{3}{*}{ Cinsiyet } & Kadın & 56 & 17 \\
\hline & Erkek & 274 & 83 \\
\hline & Toplam & 330 & 100 \\
\hline \multirow{8}{*}{ Eğitim Düzeyi } & İlkokul Terk & 6 & 1.8 \\
\hline & İlkokul & 51 & 15.5 \\
\hline & Ortaokul & 78 & 23.6 \\
\hline & Düz Lise & 109 & 33 \\
\hline & Meslek Lisesi & 10 & 3 \\
\hline & Ön Lisans & 28 & 8.5 \\
\hline & Lisans Ve üzeri & 48 & 14.5 \\
\hline & Toplam & 330 & 100 \\
\hline \multicolumn{4}{|l|}{ Tablo 1 devamı } \\
\hline & Evli & 251 & 76.1 \\
\hline Medeni Hali & Bekar & 79 & 23.9 \\
\hline
\end{tabular}


İ̧syeri Sahiplerinin Öğrenmeye İlişkin Tutumları ile Ekonomi Okuryazarlıkları

\begin{tabular}{llcc}
\hline & Toplam & 330 & 100 \\
\hline & $0-2000$ & 66 & 20 \\
& $2001-4000$ & 132 & $\mathbf{4 0}$ \\
Aylık Gelir (TL) & $4001-6000$ & 71 & 21.5 \\
& $6001-8000$ & 30 & 9.1 \\
& $8001-10000$ & 16 & 4.8 \\
& $10000+$ & 15 & 4.5 \\
& Toplam & 330 & 100 \\
\hline & $0-5$ & 85 & $\mathbf{2 5 . 8}$ \\
& $6-10$ & 74 & 22.4 \\
İş Deneyimi (Y11) & $11-15$ & 71 & 21.5 \\
& $16-20$ & 41 & 12.4 \\
& $21-25$ & 24 & 7.3 \\
& 25 y1l ve üzeri & 35 & 10.6 \\
& Toplam & 330 & 100 \\
\hline
\end{tabular}

Tablo 1'den görüldüğü gibi, katılımcıların yaş değişkenine göre dağılımında ağırlık 26-45 yaş aralığında olup, bu iki grubun payı \%59.7'dir. Katılımcıların cinsiyetine göre dağılımda, \%83'lük payla erkekler çoğunluktadır. Katılımcıların eğitim düzeyine göre dağılımda, sırasıyla düz lise mezunları (\%33), ortaokul mezunları (\%23.6) ve ilkokul mezunları (\%15.5) öne çıkmıştır. Katılımcıların büyük çoğunluğu ise evlidir (\%76.1). Gelir düzeyine göre dağılıma bakıldığında aylık gelirinin 2.001-4.000 TL. aralığında olduğunu beyan edenler \%40, 4.001-6.000 TL. arasında olduğunu beyan edenlerin payı ise \%21.5 olmuştur. Aylık gelirinin 2.000 TL ve altında olduğunu beyan edenlerin payı da düşük olmayıp \%20'dir. Ekonomik faaliyetteki deneyim süresine göre dağılımda ise, ağırlıklı birikim 0-15 yıl aralığında olmuştur. Katılımcıların deneyim süresine göre en yüksek frekans, 0-5 yıl aralığındaki yeni işletmelerin olmuştur (\%25.8). 20 yıldan daha uzun bir süredir işyerini işletmekte olanların payı ise $(\% 7.3+$ \%10.6) \%17.9'dur. Buna göre, çoğunluğu lise ve altı eğitim düzeyinde olan ve şu anda yürüttüğü işle ilgili deneyimi az olan evli erkeklerin oluşturduğu bir çalışma grubu söz konusudur.

Bunlara ek olarak, Mersin Ticaret ve Sanayi Odası'nın ildeki ekonomik faaliyetleri sınıflandırmak için kullandığı 41 maddelik liste, anket kodlaması için kullanılmış olup, bunların 26'sının örneklem içine dahil olduğu görülmüştür. Listenin uzun olması nedeniyle tabloya yerleştirilmemiş olan bu dağılımdaki en yüksek frekanslı etkinlikler şöyledir: Katılımcıların \%23.6'sı Lokanta-Kafeterya-Pastane, \%15.8'i Perakende Gıda ve Muhtelif Ticaret, \%13.9'u Seyahat Konaklama Eğlence Sanat ve Spor İşletmeleri, \%7.6's1 Tekstil Konfeksiyon ve Ayakkabı Ticareti, \%7.3'ü Bilgisayar Elektrik Elektronik Telekomünikasyon ve Büro Cihazları, \%3.9'u Mobilya Halı ve Ev Eşyası, \%3.6'sı Kırtasiye Matbaa Reklam Basın-Yayın Hizmetleri ve geriye kalanları diğer ekonomik faaliyetleri yürütmektedir.

Katılımcıların öğrenmeye yönelik tutum ve ekonomi okuryazarlı̆̆ı puanları. Çalışma grubunu oluşturan katılımcıların öğrenme tutumları ile ekonomik okuryazarlık düzeylerine ilişkin puanların gösterilmesi, demografik değişkenlere göre analize başlamadan önce yararlı olacaktır. Tablo 2, katılımcıların ekonomi okuryazarlığı ve öğrenmeye yönelik tutumlarına ilişkin betimsel istatistik değerlerini göstermektedir.

Tablo 2. Ekonomi Okuryazarlığı ve Öğrenmeye Yönelik Tutumların Betimsel Değerleri

\begin{tabular}{lccccc} 
Items & N & Mean & SD & Min. & Max. \\
Ekonomi Bilgisi & 330 & 3.294 & 0.945 & 1.000 & 5.000 \\
Ekonomik Akılcılık & 330 & 3.838 & 0.927 & 1.000 & 5.000 \\
Toplumsal Ekonomik Yansımalar & 330 & 3.953 & 0.795 & 1.380 & 5.000 \\
Bireysel Ekonomi Planlama & 330 & $\mathbf{4 . 3 0 6}$ & 0.842 & 1.000 & 5.000 \\
Ekonomi Okuryazarlığ Genel & 330 & 3.694 & 0.737 & 1.700 & 5.000 \\
Öğrenmeye İlişkin Tutum & 330 & $\mathbf{4 . 2 2 0}$ & 0.721 & 1.220 & 5.000 \\
\hline
\end{tabular}

Araştırmaya katılan işyeri sahiplerinin "ekonomi bilgisi" düzeyi orta (3.294 \pm 0.945$)$; "ekonomik akılcılık" düzeyi yüksek (3.838 \pm 0.927$)$; “toplumsal ekonomik yansımalar” düzeyi yüksek (3.953 \pm 0.795$)$; "bireysel ekonomi planlama" düzeyi çok yüksek $(4,306 \pm 0,842)$; “ekonomi okuryazarlığı genel” düzeyi yüksek (3.694 \pm 0.737$)$;

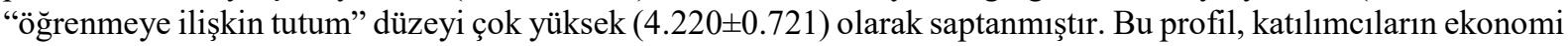
okuryazarlığı düzeyinin orta düzeyde olmasına karş1lık, öğrenmeye yönelik tutum düzeyinin çok daha yüksek olduğunu göstermektedir. Büyük çoğunluğu lise ve altı eğitim düzeyine sahip bir kitle için böyle bir yapının olumlu olduğu söylenebilir. 


\section{Veri Toplama Araçları}

$\mathrm{Bu}$ araştırmanın veri toplama aracı, üç kısımdan oluşan bir anket formudur. Birinci kısımda temel demografik verilerle ilgili sorular, ikinci kısımda Ekonomi Okuryazarlığı Ölçeği ve son kısımda Öğrenmeye İlişsin Tutum Ölçeği olmak üzere toplam 49 maddelik bir anket formu uygulanmıştır. Anket uygulaması, araştırmaya katkı yapmayı kabul eden işyeri sahipleriyle yüzyüze görüşülerek gerçekleştirilmiştir.

Öğrenmeye İlişkin Tutum Ölçeği olarak, Kara' (2010) nın geliştirmiş olduğu, 4 alt boyutlu Öğrenmeye İlişkin Tutum Ölçeğinin, öğrenme davranışı öncesindeki algıyı temsil etmesi nedeniyle "Beklenti" alt boyutu seçilmiştir. Ekonomi Okuryazarlığı Ölçeği ise, Gerek ve Kurt (2011) tarafından geliştirilmiş 4 alt boyutlu bir ölçek olup, ölçeğin tümü anket formunda kullanılmıştır. Bu ölçek "Ekonomi Bilgisi", "Ekonomik Akılcılık", "Toplumsal Ekonomik Yansımalar" ve "Bireysel Ekonomi Planlama" boyutlarından oluşmaktadır. Her iki ölçekte de Likert tipi beşli derecelendirme kullanılmıştır.

Bu araştırmada Ekonomi Okuryazarlığı Ölçeğinin güvenirliği Cronbach's Alpha= 0.949 değeriyle çok yüksek, Öğrenmeye İlişkin Tutum Ölçeğinin güvenirliği ise, Cronbach's Alpha= 0.881 değeriyle yüksek bulunmuştur.

\section{Verilerin Toplanması}

Anket uygulaması, üniversite öğrencisi olan dört anketör ve iki araştırmacı tarafindan yürütülmüştür. Üniversite öğrencisi olan anketörler, Erdemli Meslek Yüksekokulunda öğrenim gören gönüllülerden oluşmaktadır. Anketör öğrencilerin eğitimi, iki aşamalı ve 4 saatlik bir kurs sürecini gerekli kılmıştır. Bu eğitimde ilk olarak bir araştırmanın insanlara tanıtılması, kişilerin bir ankete katılımı için ikna edilmesi ve anket uygulamasına ilişkin yöntemler tartışılmıştır. Sonraki aşamada, öğrencilerin kendi tanıdıklarına uyguladıkları deneme anketlerine geçilmiştir. Daha sonra esas uygulama başlatılmış olup, tamamlanması bir ay sürmüştür.

Anket uygulaması için Mersin kent sakinlerinin yaşadığı bölgeler, anketör sayısına uygun biçimde altıya bölünmüștür. Her öğrenci kendi bölgesindeki anket uygulamalarını günlük olarak teslim etmiş ve teslim alınan anket formları günlük olarak kontrol edilerek kaydedilmiştir. Saha raştırmalarında yaygın olarak karşılaşılan ve katılımcı adaylarından kaynaklanan yanlış anlama, aşırı tepki verme ve çeşitli nedenlerle yarıda bırakma gibi sorunlar nedeniyle, geçerli anket formu sayısı ve dolayısıyla örneklem büyüklüğü de 330 olarak gerçekleşmiştir.

\section{Verilerin Analizi}

Araştırma sorularının yapısı ve araştırma amacı, nicel analiz tekniklerinin uygulanmasııı gerekli kılmıştır. Araştırmada elde edilen veriler SPSS (Statistical Package for Social Sciences) for Windows 22.0 programı kullanılarak analiz edilmiştir. Verilerin değerlendirilmesinde tanımlayıcı istatistiksel yöntemler olarak sayı, yüzde, ortalama ve standart sapma kullanılmıştır. Ölçek boyutlarının aldığı puanlar 1 ile 5 arasında değerlendirilmiştir. Dağılım aralığının hesaplanması amacıyla, Dağıllm Aralı̆̆ $=E n$ büyük değer-En küçük değer/derece saylsı formülü kullanılmıştır. Bu aralık 4 puanlık genişliğe sahiptir. Bu genişlik beş eşit genişliğe bölünerek 1.00- 1.79 arası "çok düşük", 1.80- 2.59 arası "düşük", 2.60- 3.39 "arası orta", 3.40-4.19 arası yüksek, 4.20-5.00 arası çok yüksek olarak sınır değerleri belirlenmiş ve bulgular yorumlanmıştır (Sümbüloğlu, 1993:9).

İki bağımsız grup arasında niceliksel sürekli verilerin karşılaştırılmasında t-testi, ikiden fazla bağımsız grup arasında niceliksel sürekli verilerin karşılaştırılmasında Tek Yönlü (One Way) ANOVA testi kullanılmıştır. ANOVA testi sonrasında, farkl1lıkları belirlemek üzere tamamlayıcı Post-Hoc analizi olarak Scheffe testi kullanılmıştır. Araştırmanın sürekli değişkenleri arasındaki ilişki için Pearson Korelasyon ve regresyon analizi uygulanmıştır. Elde edilen bulgular $\% 95$ güven aralığında, $\% 5$ anlamlılık düzeyinde değerlendirilmiştir.

\section{Bulgular}

Bu başlık altında, veri toplama aracıyla elde edilmiş olan bulguların araştırma amacı ve soruları temelinde sunumu gerçekleştirilmiştir. Bu bağlamda, öncelikle ilk araştırma sorusuna ilişkin bulgular sunulmuş, daha sonra diğer bulgulara geçilmiştir.

\section{İşyeri Sahiplerinin Öğrenmeye Yönelik Tutumlarının Ekonomi Okuryazarlığına Etkisi}

Araştırma problemlerimizin ilki olan "İşyeri sahiplerinin öğrenmeye yönelik tutumlarının, ekonomi okuryazarlığına etkisi var mıdır?" sorusuna karşlık hem korelasyon hem de regrasyon analizlerinden yararlanılmıştır. Tablo 3, öğrenmeye yönelik tutum ile ekonomi yazarlığı arasındaki ilişkinin yönünü ve düzeyini 580 
açıklayan korelasyon değerlerini göstermektedir. Tablo 4 ise, öğrenmeye ilişkin tutum ile ekonomi okuryazarlığ arasındaki neden-sonuç ilişkisini sergileyen regresyon analizinin sonuçlarını aktarmaktadır.

Tablo 3. Ekonomi Okuryazarlığı ile Öğrenmeye İlişkin Tutum Arasında Korelasyon Analizi

\begin{tabular}{|c|c|c|c|c|c|c|c|}
\hline & & 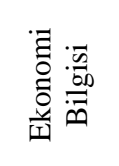 & 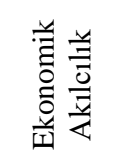 & 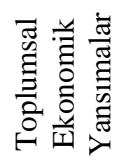 & 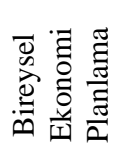 & 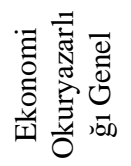 & 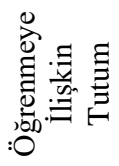 \\
\hline \multirow{2}{*}{ Ekonomi Bilgisi } & $\mathrm{r}$ & 1.000 & & & & & \\
\hline & $\mathrm{p}$ & 0.000 & & & & & \\
\hline \multirow{2}{*}{ Ekonomik Akılcılık } & $\mathrm{r}$ & $0.600 * *$ & 1.000 & & & & \\
\hline & $\mathrm{p}$ & 0.000 & 0.000 & & & & \\
\hline \multirow{2}{*}{ Toplumsal Ekonomik Yansımalar } & $\mathrm{r}$ & $0.479 * *$ & $0.711 * *$ & 1.000 & & & \\
\hline & $\mathrm{p}$ & 0.000 & 0.000 & 0.000 & & & \\
\hline \multirow{2}{*}{ Bireysel Ekonomi Planlama } & $\mathrm{r}$ & $0.228 * *$ & $0.451 * *$ & $0.550 * *$ & 1.000 & & \\
\hline & $\mathrm{p}$ & 0.000 & 0.000 & 0.000 & 0.000 & & \\
\hline \multirow{2}{*}{ Ekonomi Okuryazarlığı Genel } & $\mathrm{r}$ & $0.860 * *$ & $0.879 * *$ & $0.805 * *$ & $0.518 * *$ & 1.000 & \\
\hline & $\mathrm{p}$ & 0.000 & 0.000 & 0.000 & 0.000 & 0.000 & \\
\hline \multirow{2}{*}{ Ö̆grenmeye İlişkin Tutum } & $\mathrm{r}$ & $0.367 * *$ & $0.651 * *$ & $0.675 * *$ & $0.530 * *$ & $0.640 * *$ & 1.000 \\
\hline & $\mathrm{p}$ & 0.000 & 0.000 & 0.000 & 0.000 & 0.000 & 0.000 \\
\hline
\end{tabular}

Tablo 3 'teki bulgulara göre, ekonomi okuryazarlığı ölçeğinin alt boyutlarının birbirleri arasında ve genel ekonomi okuryazarlığı arasında pozitif yönde anlamlı ilişkiler olduğu görülmektedir. Örneğin, Ekonomik Akılcılık ile Ekonomi Bilgisi arasında orta, pozitif yönde anlamlı ilişki ( $\mathrm{r}=0.6 ; \mathrm{p}=0.000<0.05)$; Toplumsal Ekonomik Yansımalar ile Ekonomi Bilgisi arasında zayıf, pozitif yönde anlamlı ilişki $(r=0.479 ; \mathrm{p}=0.000<0.05)$ ve Ekonomi Okuryazarlığı Genel ile Ekonomi Bilgisi arasında yüksek, pozitif yönde anlamlı ilişki bulunmaktadır ( $\mathrm{r}=0.86$; $\mathrm{p}=0.000<0.05)$.

Öğrenmeye İlişkin Tutum ile Ekonomi Bilgisi arasında zayıf, pozitif yönde anlamlı ilişki bulunmakta olup, $(\mathrm{r}=0.367 ; \mathrm{p}=0.000<0.05)$ en düşük ilişki değeri bu noktada saptanmıştır. Öğrenmeye İlişkin Tutumun, Ekonomi Okuryazarlığının diğer alt boyutlarıyla ilişkisi daha güçlüdür. Örneğin, Ekonomik Akılcılık arasında orta, pozitif yönde anlamlı ilişki $(\mathrm{r}=0.651 ; \mathrm{p}=0.000<0.05)$; Toplumsal Ekonomik Yansımalar arasında orta, pozitif yönde anlamlı ilişki $(r=0.675 ; \mathrm{p}=0.000<0.05)$ vardır. Ayrıca, Öğrenmeye İlişkin Tutum ile Ekonomi Okuryazarlığı Geneli arasında da orta, pozitif yönde anlamlı ilişki çıkmıştır $(r=0.64 ; p=0.000<0.05)$. Bu sonuçlara göre, işyeri sahiplerinin ögrenmeye ilişkin tutumları ile ekonomi okuryazarlıkları arasında pozitif yönde anlamlı bir ilişki bulunmaktadır.

Tablo 4. Öğrenmeye İlişkin Tutumun Ekonomi Okuryazarlığı Geneli Üzerine Etkisi

\begin{tabular}{|c|c|c|c|c|c|c|c|}
\hline Bağımlı Değişken & Bağımsız Değişken & B & $\mathbf{t}$ & p & $\mathbf{F}$ & Model (p) & $\mathbf{R}^{2}$ \\
\hline \multirow{2}{*}{ Ekonomi Bilgisi } & Sabit & 1.264 & 4.392 & 0.000 & 51.132 & 0.000 & 0.132 \\
\hline & Öğrenmeye İlişkin Tutum & 0.481 & 7.151 & 0.000 & & & \\
\hline \multirow{2}{*}{ Ekonomik Ak1lc1lık } & Sabit & 0.309 & 1.341 & 0.181 & 240.769 & 0.000 & 0.422 \\
\hline & Öğrenmeye İlişkin Tutum & 0.836 & 15.517 & 0.000 & & & \\
\hline Toplumsal Ekonomik & Sabit & 0.817 & 4.249 & 0.000 & 274.140 & 0.000 & 0.454 \\
\hline Yansimalar & Öğrenmeye İlişkin Tutum & 0.743 & 16.557 & 0.000 & & & \\
\hline \multirow{2}{*}{ Bireysel Ekonomi Planlama } & Sabit & 1.697 & 7.257 & 0.000 & 128.096 & 0.000 & 0.279 \\
\hline & Öğrenmeye Ilisskin Tutum & 0.618 & 11.318 & 0.000 & & & \\
\hline Ekonomi Okuryazarlığı & Sabit & 0.935 & 5.038 & 0.000 & 227.686 & 0.000 & 0.408 \\
\hline Genel & Öğrenmeye İlişkin Tutum & 0.654 & 15.089 & 0.000 & & & \\
\hline
\end{tabular}

Tablo 4'teki bulgulardan görüldüğü gibi, Öğrenmeye İlişkin Tutum ile Ekonomi Bilgisi, Ekonomik Akılcılık, Toplumsal Ekonomik Yansımalar, Bireysel Ekonomi Planlama ve Ekonomi Okuryazarlı̆̆ Geneli arasındaki neden sonuç ilişkisini belirlemek üzere yapılan regresyon analizleri istatistiksel olarak anlamlı bulunmuştur $(\mathrm{F}=51.132 ; \mathrm{F}=240.769 ; \mathrm{F}=274.140 ; \mathrm{F}=128.096$ ve $\mathrm{F}=227.686 ; \mathrm{p}=0.000<0.05)$. Ekonomi Bilgisi düzeyinin belirleyicisi olarak Öğrenmeye İlişkin Tutum değişkenleri ile ilişkisinin (açıklayıcılık gücünün) zayıf olduğu görülmüştür $\left(\mathrm{R}^{2}=0.132\right)$. İşyeri sahiplerinin Öğrenmeye İlişkin Tutum düzeyi, Ekonomi Bilgisi düzeyini 
arttırmaktadır ( $(=0.481)$. Ekonomik Akılcılık düzeyinin belirleyicisi olarak Öğrenmeye İlişkin Tutum değişkenleri ile ilişkisinin (açıklayıcılık gücünün) çok güçlü olduğu görülmüştür $\left(\mathrm{R}^{2}=0.422\right)$. İşyeri sahiplerinin Öğrenmeye İlişkin Tutum düzeyi, Ekonomik Akılcılık düzeyini arttırmaktadır ( $(=0.836)$.

Toplumsal Ekonomik Yansımalar düzeyinin belirleyicisi olarak Öğrenmeye İlişkin Tutum değişkenleri ile ilişkisinin çok güçlü olduğu görülmüştür $\left(\mathrm{R}^{2}=0.454\right)$. İşyeri sahiplerinin Öğrenmeye İlişkin Tutum düzeyi, Toplumsal Ekonomik Yansımalar düzeyini arttırmaktadır $(\beta=0.743)$. Bireysel Ekonomi Planlama düzeyinin belirleyicisi olarak Öğrenmeye İlişkin Tutum değişkenleri ile ilişkisinin de güçlü olduğu görülmüştür $\left(\mathrm{R}^{2}=0.279\right)$. İşyeri sahiplerinin Öğrenmeye İlişkin Tutum düzeyi, Bireysel Ekonomi Planlama düzeyini arttırmaktadır $(\beta=0.618)$. Ekonomi Okuryazarlığı Genel düzeyinin belirleyicisi olarak Öğrenmeye İliş̧kin Tutum değişkenleri ile ilişkisinin de güçlü olduğu görülmüştür $\left(\mathrm{R}^{2}=0.408\right)$. İşyeri sahiplerinin Öğrenmeye İlişkin Tutum düzeyi, Ekonomi Okuryazarlığı Genel düzeyini arttırmaktadır $(\beta=0.654)$.

Yukarıdaki bulgulara dayanarak, işyeri sahiplerinin öğrenmeye ilişkin tutumlarının, ekonomi okuryazarlı̆ğ düzeylerine etkisi olduğu söylenebilir. Başka bir deyişle, işyeri sahiplerinin öğrenmeye karşı tutum düzeyleri olumlu yönde arttıkça, bu artışın ekonomi okuryazarlığı düzeylerine de olumlu yönde yansıması beklenebilir. Bunun nedeni olarak, yukarıdaki araştırma örneklerinde vurgulandığı gibi, birşeyler öğrenmeye açık olan bireylerin, okuryazarlık türlerine ilişkin yeterliklerini geliştirebilme olanaklarını daha kolay değerlendirebilmeleri gösterilebilir.

\section{İşyeri Sahiplerinin Yaş, Cinsiyet ve Medeni Durumlarının Ekonomi Okuryazarlığına ve Öğrenmeye Yönelik Tutuma Etkisi}

"İşyeri sahiplerinin yaş, cinsiyet ve medeni hallerinin, ekonomi okuryazarlığına ve öğrenmeye yönelik tutumlarına etkisi var mıdır?" sorusuna yönelik yapılan analizler, Tablo 5 ve 6'da sunulmuştur. Tablo 5, yaş değişkenine göre analiz sonuçlarını göstermektedir.

Tablo 5. Ekonomi Okuryazarlığı ile Öğrenmeye İlişkin Tutumun Yaş Değişkeninin Etkisine Göre Karşılaştırılması

\begin{tabular}{|c|c|c|c|c|c|c|c|}
\hline $\begin{array}{l}\text { Demografi } \\
\text { k Değişken }\end{array}$ & $\mathbf{n}$ & $\begin{array}{c}\text { Ekonomi } \\
\text { Bilgisi }\end{array}$ & $\begin{array}{c}\text { Ekonomik } \\
\text { Akılcıllkk }\end{array}$ & $\begin{array}{c}\text { Toplumsal } \\
\text { Ekonomik } \\
\text { Yansımalar }\end{array}$ & $\begin{array}{l}\text { Bireysel } \\
\text { Ekonomi } \\
\text { Planlama }\end{array}$ & $\begin{array}{c}\text { Ekonomi } \\
\text { Okuryazarlığ } \\
\text { I Genel }\end{array}$ & $\begin{array}{c}\text { Öğgrenmeye } \\
\text { İlişkin } \\
\text { Tutum }\end{array}$ \\
\hline Yaş & & Ort \pm SS & Ort \pm SS & Ort \pm SS & Ort \pm SS & Ort $\pm \mathrm{SS}$ & Ort \pm SS \\
\hline $18-25$ & 26 & $\begin{array}{c}2.817 \pm 1.10 \\
3\end{array}$ & $\begin{array}{c}3.551 \pm 0.80 \\
6\end{array}$ & $\begin{array}{c}3.664 \pm 0.71 \\
1\end{array}$ & $\begin{array}{c}4.449 \pm 0.72 \\
4\end{array}$ & $3.371 \pm 0.651$ & $\begin{array}{c}4.175 \pm 0.64 \\
9\end{array}$ \\
\hline $26-35$ & 74 & $\begin{array}{c}3.201 \pm 0.89 \\
6\end{array}$ & $\begin{array}{c}3.730 \pm 0.89 \\
7\end{array}$ & $\begin{array}{c}3.627 \pm 0.82 \\
1\end{array}$ & $\begin{array}{c}4.000 \pm 0.95 \\
2\end{array}$ & $3.521 \pm 0.732$ & $\begin{array}{c}3.911 \pm 0.83 \\
3\end{array}$ \\
\hline $36-45$ & $\begin{array}{c}12 \\
3\end{array}$ & $\begin{array}{c}3.338 \pm 0.91 \\
8\end{array}$ & $\begin{array}{c}3.783 \pm 1.02 \\
3\end{array}$ & $\begin{array}{c}3.941 \pm 0.85 \\
7\end{array}$ & $\begin{array}{c}4.255 \pm 0.85 \\
5\end{array}$ & $3.689 \pm 0.785$ & $\begin{array}{c}4.180 \pm 0.76 \\
0\end{array}$ \\
\hline $46-55$ & 75 & $\begin{array}{c}3.332 \pm 0.93 \\
2\end{array}$ & $\begin{array}{c}4.033 \pm 0.88 \\
1\end{array}$ & $\begin{array}{c}4.257 \pm 0.55 \\
5\end{array}$ & $\begin{array}{c}4.511 \pm 0.71 \\
7\end{array}$ & $3.855 \pm 0.659$ & $\begin{array}{c}4.449 \pm 0.50 \\
8\end{array}$ \\
\hline $56-75$ & 32 & $\begin{array}{c}3.637 \pm 0.92 \\
8\end{array}$ & $\begin{array}{c}4.076 \pm 0.68 \\
7\end{array}$ & $\begin{array}{c}4.277 \pm 0.65 \\
0\end{array}$ & $\begin{array}{c}4.615 \pm 0.63 \\
4\end{array}$ & $4.001 \pm 0.613$ & $\begin{array}{c}4.587 \pm 0.40 \\
0\end{array}$ \\
\hline $\mathrm{F}=$ & & 3.070 & 2.376 & 8.829 & 5.188 & 4.761 & 8.109 \\
\hline $\mathrm{p}=$ & & 0.017 & 0.052 & 0.000 & 0.000 & 0.001 & 0.000 \\
\hline $\begin{array}{l}\text { İleri Test } \\
(\mathrm{MWU})=\end{array}$ & & $\begin{array}{l}3>1,4>1, \\
5>1,5>2 \\
(p<0.05)\end{array}$ & & $\begin{array}{c}4>1,5>1, \\
3>2,4>2, \\
5>2,4>3, \\
5>3 \\
(p<0.05)\end{array}$ & $\begin{array}{l}1>2,3>2, \\
4>2,5>2, \\
4>3,5>3 \\
(p<0.05)\end{array}$ & $\begin{array}{l}3>1,4>1, \\
5>1,4>2, \\
5>2,5>3 \\
(p<0.05)\end{array}$ & $\begin{array}{l}5>1,3>2, \\
4>2,5>2, \\
4>3,5>3 \\
(p<0.05)\end{array}$ \\
\hline
\end{tabular}

Tablo 5'teki bulgulara göre şunlar söylenebilir: Araştırmaya katılan işyeri sahiplerinin Ekonomi Bilgisi, Ekonomik Akılcılık, Toplumsal Ekonomik Yansımalar, Bireysel Ekonomi Planlama, Ekonomi Okuryazarlı̆ı Genel ve Öğrenmeye İlişkin Tutum puanları ortalamalarının yaş değişkeni açısından anlamlı bir farklılık gösterip göstermediğini belirlemek amacıyla yapılan Tek Yönlü Varyans Analizi (ANOVA) sonuçlarına göre, Ekonomik Akzlcıllk alt boyutu dışındaki tüm grup ortalamaları arasındaki fark anlamlı bulunmuştur( $\mathrm{F}=3.070 \mathrm{p}=0.017<0.05$; $\mathrm{F}=2.376 \mathrm{p}=0.052 ; \mathrm{F}=8.829 \mathrm{p}=0.000 ; \mathrm{F}=5.188 \mathrm{p}=0.000 ; \mathrm{F}=4.761 \mathrm{p}=0.001$ ve $\mathrm{F}=8.109 \mathrm{p}=0.000$ ). Dolayısıyla, işyeri 
sahiplerinin yaşlarının, ekonomik akılcılık alt boyutu hariç olmak üzere, ekonomi okuryazarlığı düzeylerini etkileyebildiği görülmüştür. Yaş arttıkça, genel ekonomi okuryazarlığı düzeyi ortalamasının yükseldiği söylenebilir. Ayrıca, öğrenmeye ilişkin tutum düzeyi de yaşla birlikte değişebilmektedir. Bu durum, gençlik dönemindeki "herşeyi biliyorum" algısından, olgunlaştıkça "öğrenecek çok şeyin olabileceği"ni kabullenmeye geçişle açıklanabilir.

Tablo 6. Ekonomi Okuryazarlığı ile Öğrenmeye İlişkin Tutumun Cinsiyet ve Medeni Durum Değgişkenlerinin Etkisine Göre Karşılaştırılması

\begin{tabular}{|c|c|c|c|c|c|c|c|}
\hline $\begin{array}{l}\text { Demografik } \\
\text { Değişken }\end{array}$ & $\mathbf{n}$ & $\begin{array}{c}\text { Ekonomi } \\
\text { Bilgisi }\end{array}$ & $\begin{array}{l}\text { Ekonomik } \\
\text { Akılcılık }\end{array}$ & $\begin{array}{c}\text { Toplumsal } \\
\text { Ekonomik } \\
\text { Yansımalar }\end{array}$ & $\begin{array}{c}\text { Bireysel } \\
\text { Ekonomi } \\
\text { Planlama } \\
\end{array}$ & $\begin{array}{c}\text { Ekonomi } \\
\text { Okuryazarlığı } \\
\text { Genel }\end{array}$ & $\begin{array}{c}\text { Ö̆grenmeye } \\
\text { İlişkin Tutum }\end{array}$ \\
\hline Cinsiyet & & Ort \pm SS & Ort \pm SS & Ort \pm SS & Ort \pm SS & Ort \pm SS & Ort \pm SS \\
\hline Kadın & 56 & $3.114 \pm 0.995$ & $3.978 \pm 0.834$ & $4.054 \pm 0.758$ & $4.357 \pm 0.786$ & $3.691 \pm 0.669$ & $4.369 \pm 0.645$ \\
\hline Erkek & 274 & $3.331 \pm 0.932$ & $3.809 \pm 0.944$ & $3.933 \pm 0.802$ & $4.296 \pm 0.853$ & $3.695 \pm 0.751$ & $4.189 \pm 0.733$ \\
\hline $\mathrm{T}=$ & & -1.568 & 1.242 & 1.039 & 0.498 & -0.041 & 1.703 \\
\hline $\mathrm{p}=$ & & 0.118 & 0.215 & 0.299 & 0.619 & 0.968 & 0.089 \\
\hline Medeni Durum & & Ort \pm SS & Ort \pm SS & Ort \pm SS & $\mathrm{Ort} \pm \mathrm{SS}$ & Ort \pm SS & Ort \pm SS \\
\hline Evli & 251 & $3.310 \pm 0.913$ & $3.863 \pm 0.905$ & $3.998 \pm 0.785$ & $4.317 \pm 0.822$ & $3.719 \pm 0.718$ & $4.242 \pm 0.685$ \\
\hline Bekar & 79 & $3.243 \pm 1.043$ & $3.758 \pm 0.996$ & $3.812 \pm 0.814$ & $4.270 \pm 0.906$ & $3.615 \pm 0.793$ & $4.149 \pm 0.827$ \\
\hline$t=$ & & 0.544 & 0.879 & 1.819 & 0.436 & 1.096 & 1.000 \\
\hline $\mathrm{p}=$ & & 0.587 & 0.380 & 0.070 & 0.663 & 0.274 & 0.318 \\
\hline
\end{tabular}

Tablo 6'da görüldüğü üzere, cinsiyet ve medeni hal değişkenleriyle yapılan varyans analizi sonuçlarına göre, grup ortalamaları arasındaki fark anlamlı bulunmamıştır $(\mathrm{p}>0.05)$.

\section{İşyeri Sahiplerinin Eğitim Düzeyinin Ekonomi Okuryazarlığına ve Öğrenmeye İlişkin Tutuma Etkisi}

"İşyeri sahiplerinin eğitim düzeyinin, ekonomi okuryazarlığına ve öğrenmeye yönelik tutumlarına etkisi var mıdır?" sorusuna yönelik yapılan analizlerin bulguları Tablo 7'de gösterilmiştir.

Tablo 7. Ekonomi Okuryazarlığı ile Öğrenmeye İlişkin Tutumun Eğitim Düzeyinin Etkisine Göre Karşılaştırılması

\begin{tabular}{|c|c|c|c|c|c|c|c|}
\hline \multicolumn{2}{|c|}{$\begin{array}{l}\text { Demografik } \\
\text { Değişken }\end{array}$} & $\begin{array}{c}\text { Ekonomi } \\
\text { Bilgisi }\end{array}$ & $\begin{array}{l}\text { Ekonomik } \\
\text { Akılcılık }\end{array}$ & $\begin{array}{c}\text { Toplumsal } \\
\text { Ekonomik } \\
\text { Yansımalar }\end{array}$ & $\begin{array}{c}\text { Bireysel } \\
\text { Ekonomi } \\
\text { Planlama }\end{array}$ & $\begin{array}{c}\text { Ekonomi } \\
\text { Okuryazarlığı } \\
\text { Genel }\end{array}$ & $\begin{array}{c}\text { Öğrenmeye } \\
\text { Ilişsin Tutum }\end{array}$ \\
\hline \multicolumn{2}{|c|}{ Ĕgitim Düzeyi (n) } & Ort \pm SS & Ort \pm SS & Ort \pm SS & Ort \pm SS & Ort \pm SS & Ort \pm SS \\
\hline $\begin{array}{l}\text { İlkokul ve } \\
\text { altı }\end{array}$ & 57 & $2.943 \pm 0.876$ & $3.659 \pm 0.836$ & $3.873 \pm 0.702$ & $4.216 \pm 0.813$ & $3.480 \pm 0.627$ & $3.977 \pm 0.795$ \\
\hline Ortaokul & 78 & $3.010 \pm 0.837$ & $3.702 \pm 0.868$ & $3.689 \pm 0.881$ & $4.350 \pm 0.734$ & $3.485 \pm 0.683$ & $4.113 \pm 0.762$ \\
\hline Düz lise & 109 & $343 \pm 0.985$ & $3.886 \pm 1.019$ & $4.060 \pm 0.776$ & $4.376 \pm 0.861$ & $3.759 \pm 0.782$ & $4.337 \pm 0.669$ \\
\hline $\begin{array}{l}\text { Meslek } \\
\text { lisesi }\end{array}$ & 10 & $3.346 \pm 0.691$ & $3.489 \pm 1.298$ & $3.550 \pm 1.195$ & $3.867 \pm 1.354$ & $3.482 \pm 0.918$ & $4.178 \pm 0.895$ \\
\hline Ön lisans & 28 & $3.420 \pm 0.794$ & $3.893 \pm 0.813$ & $4.071 \pm 0.624$ & $4.262 \pm 0.624$ & $3.784 \pm 0.581$ & $4.270 \pm 0.575$ \\
\hline $\begin{array}{l}\text { Lisans ve } \\
\text { üzeri }\end{array}$ & 48 & $3.976 \pm 0.853$ & $4.204 \pm 0.787$ & $4.250 \pm 0.630$ & $4.299 \pm 0.971$ & $4.134 \pm 0.677$ & $4.396 \pm 0.641$ \\
\hline $\mathrm{F}=$ & & 9.162 & 2.682 & 4.429 & 0.884 & 6.567 & 2.908 \\
\hline $\mathrm{p}=$ & & 0.000 & 0.022 & 0.001 & 0.492 & 0.000 & 0.014 \\
\hline $\begin{array}{l}\text { İleri Test } \\
(\mathrm{MWU})=\end{array}$ & & $\begin{array}{c}3>1,5>1, \\
6>1,3>2, \\
5>2,6>2, \\
6>3,6>4,6>5 \\
(\mathrm{p}<0.05)\end{array}$ & $\begin{array}{l}6>1,6>2, \\
6>3,6>4 \\
(p<0.05)\end{array}$ & $\begin{array}{l}6>1,3>2, \\
5>2,6>2, \\
3>4,6>4 \\
(p<0.05)\end{array}$ & & $\begin{array}{c}3>1,6>1,3>2, \\
6>2,6>3,6>4 \\
6>5(p<0.05)\end{array}$ & $\begin{array}{c}3>1,6>1,3>2, \\
6>2(p<0.05)\end{array}$ \\
\hline
\end{tabular}

Tablo 7'de yer verilmiş olan analiz sonuçlarına göre, araştırmaya katılan işyeri sahiplerinin Ekonomi Bilgisi, Ekonomik Akılcılık, Toplumsal Ekonomik Yansımalar, Ekonomi Okuryazarlığı Genel ve Öğrenmeye İlişkin Tutum puanları ortalamalarının eğitim durumu değişkeni açısından anlamlı bir farklılık gösterip göstermediğini belirlemek amacıyla yapılan Tek Yönlü Varyans Analizi (ANOVA) sonuçlarına göre, grup ortalamaları arasındaki fark anlamlı bulunmuştur $(\mathrm{F}=9.162 ; \mathrm{F}=2.682 ; \mathrm{F}=4.429 ; \mathrm{F}=6.567$ ve $\mathrm{F}=2.908 \mathrm{p}<0.05)$. Fakat, işyeri sahiplerinin Bireysel Ekonomi Planlama puanları ortalamaları arasındaki fark, eğitim değişkeni açısından anlamlı bulunmamıştır $(\mathrm{F}=0.884, \mathrm{p}=0.492>0.05)$. 
Araştırmaya katılan işyeri sahiplerinin Öğrenmeye İlişkin Tutum puanları ortalamalarının eğitim durumu değişkeni açısından anlamlı bir farklılık gösterip göstermediğini belirlemek amaciyla yapılan varyans analizi sonuçlarına göre, grup ortalamaları arasındaki fark anlamlı bulunmuştur $(\mathrm{F}=2.908 ; \mathrm{p}=0.014<0.05)$. Farklılı̆̆ın hangi gruptan kaynaklandığını belirlemek üzere PostHoc testi uygulanmıştır. Buna göre eğitim durumu düz lise

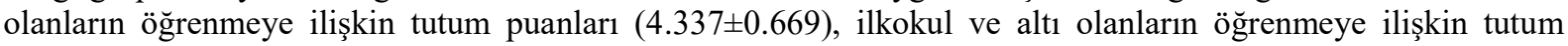
puanlarından (3.977 \pm 0.795$)$, eğitim durumu lisans ve üzeri olanların öğrenmeye ilişkin tutum puanları (4.396 \pm 0.641$)$, ilkokul ve altı olanların öğrenmeye ilişkin tutum puanlarından (3.977 \pm 0.795$)$, eğitim durumu düz

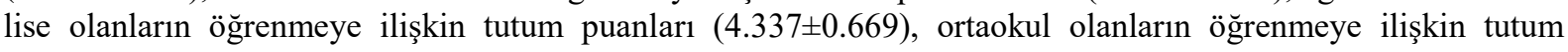
puanlarından $(4.113 \pm 0.762)$ ve eğitim durumu lisans ve üzeri olanların öğrenmeye ilişkin tutum puanları

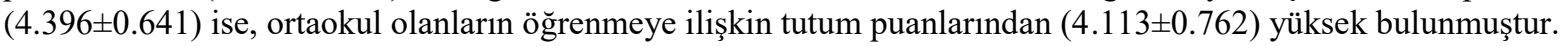

Bu bulgulara dayanarak, Bireysel Ekonomi Planlama alt boyutu hariç olmak üzere, Ekonomi Okuryazarlığının diğer alt boyutları ile genel ekonomi okuryazarlık düzeylerinin ve öğrenmeye ilişkin tutumlarının, işyeri sahiplerinin eğitim düzeyi ile birlikte değişebileceği söylenebilir. Başka bir ifadeyle, işyeri sahiplerinin eğitim düzeyi yükseldikçe, hem ekonomi okuryazarlığı hem de öğrenmeye ilişkin tutum puanlarının ortalamaları da artabilmektedir. Bu durum, ekonomi okuryazarlı̆̆ının bilgiye dayalı karakteristiğine uygun düşer. Öğrenmeye ilişkin tutum puanlarının eğitim düzeyiyle birlikte değişebilmesi ise, ulusal ve uluslararası çeşitli araştırmalarda elde edilen bulgulara paraleldir. Bireylerin eğitim düzeyinin yükselmesi, öğrenme ürünlerinin değerinin anlaşılmasına ve dolayısıyla öğrenmeye ilişkin yaklaşımların ve eğilimlerin olumlu yönde değişmesine katkı yapabilir.

\section{İşyeri Sahiplerinin Aylık Gelir Düzeyi ile İş Deneyimi Süresinin Ekonomi Okuryazarlı̆̆ına ve Öğrenmeye Yönelik Tutuma Etkisi}

"İşyeri sahiplerinin gelir düzeyinin, ekonomi okuryazarllğına ve öğrenmeye yönelik tutumlarına etkisi var mıdır?" ile "İ̧̧yeri sahiplerinin iş deneyimi süresinin, ekonomi okuryazarlığına ve öğrenmeye yönelik tutuma etkisi var mıdır?" araştırma sorularına yönelik olarak, aşağıdaki analiz bulgularına ulaşılmıştır.

Araştırmaya katılan işyeri sahiplerinin Ekonomi Bilgisi puanları ortalamalarının gelir düzeyi değiş̧eni açısından anlamlı bir farklılık gösterip göstermediğini belirlemek amacıyla yapılan Tek Yönlü Varyans Analizi sonuçlarına göre, grup ortalamaları arasındaki fark anlamlı bulunmuştur $(\mathrm{F}=2.436 ; \mathrm{p}=0.047<0.05)$. Buna göre, işyeri sahiplerinin aylık geliri yükseldikçe, ekonomi bilgisi düzeyi de birlikte değiş̧ebilmektedir. Bu durum, artan bir gelirin finansal piyasalarda kullanılması sürecinde daha fazla bilgiye gerek duyulmasıyla açıklanabilir. Bununla birlikte, işyeri sahiplerinin Ekonomik Akılcılık, Toplumsal Ekonomik Yansımalar, Bireysel Ekonomi Planlama, Ekonomi Okuryazarlığı Genel ve Öğrenmeye İlişkin Tutum puanları ortalamalarının gelir düzeyi açısından grup ortalamaları arasındaki fark anlamlı bulunmamıştır ( $\mathrm{p}>0.05)$.

Tablo 8, katılımcıların yürütmekte olduğu ekonomik faaliyetteki deneyim süresine ilişkin bulguları göstermektedir.

Tablo 8. Ekonomi Okuryazarlığı ile Öğrenmeye İlişkin Tutumun İş Deneyimi Süresine Göre Karşılaştırılması

\begin{tabular}{|c|c|c|c|c|c|c|c|}
\hline $\begin{array}{l}\text { Demografik } \\
\text { Değişken }\end{array}$ & $\mathbf{n}$ & $\begin{array}{c}\text { Ekonomi } \\
\text { Bilgisi }\end{array}$ & $\begin{array}{c}\text { Ekonomik } \\
\text { Akılcılık }\end{array}$ & $\begin{array}{c}\text { Toplumsal } \\
\text { Ekonomik } \\
\text { Yansımalar } \\
\end{array}$ & $\begin{array}{c}\text { Bireysel } \\
\text { Ekonomi } \\
\text { Planlama } \\
\end{array}$ & $\begin{array}{c}\text { Ekonomi } \\
\text { Okuryazarlığı } \\
\text { Genel }\end{array}$ & $\begin{array}{c}\text { Ö̆̆grenmeye } \\
\text { Illişkin Tutum }\end{array}$ \\
\hline Deneyim(yıl) & & Ort \pm SS & Ort \pm SS & Ort \pm SS & Ort \pm SS & Ort \pm SS & Ort \pm SS \\
\hline $0-5$ & 85 & $3.063 \pm 0.931$ & $3.492 \pm 0.949$ & $3.544 \pm 0.802$ & $4.059 \pm 0.896$ & $3.387 \pm 0.744$ & $3.873 \pm 0.831$ \\
\hline $6-10$ & 74 & $3.258 \pm 0.904$ & $3.814 \pm 0.878$ & $3.907 \pm 0.739$ & $4.284 \pm 0.833$ & $3.660 \pm 0.675$ & $4.177 \pm 0.721$ \\
\hline $11-15$ & 71 & $3.091 \pm 1.026$ & $3.776 \pm 1.059$ & $4.018 \pm 0.825$ & $4.380 \pm 0.895$ & $3.620 \pm 0.820$ & $4.352 \pm 0.679$ \\
\hline $16-20$ & 41 & $3.443 \pm 0.859$ & $4.108 \pm 0.766$ & $4.162 \pm 0.750$ & $4.382 \pm 0.780$ & $3.884 \pm 0.614$ & $4.396 \pm 0.509$ \\
\hline $21-25$ & 24 & $3.872 \pm 0.774$ & $4.037 \pm 0.806$ & $4.349 \pm 0.626$ & $4.500 \pm 0.637$ & $4.090 \pm 0.609$ & $4.482 \pm 0.513$ \\
\hline 25 yıl üzeri & 35 & $3.771 \pm 0.762$ & $4.403 \pm 0.495$ & $4.396 \pm 0.471$ & $4.581 \pm 0.683$ & $4.169 \pm 0.438$ & $4.498 \pm 0.524$ \\
\hline $\mathrm{F}=$ & & 5.885 & 6.465 & 9.720 & 2.727 & 8.917 & 7.247 \\
\hline $\mathrm{p}=$ & & 0.000 & 0.000 & 0.000 & 0.020 & 0.000 & 0.000 \\
\hline $\begin{array}{l}\text { İleri Test } \\
(\mathrm{MWU})=\end{array}$ & & $\begin{array}{c}4>1,5>1,6>1, \\
5>2,6>2,4>3, \\
5>3,6>3 \\
(p<0.05)\end{array}$ & $\begin{array}{c}2>1,3>1,4>1, \\
5>1,6>1,6>2, \\
6>3(p<0.05)\end{array}$ & $\begin{array}{c}2>1,3>1,4>1, \\
5>1,6>1,5>2, \\
\quad 6>2,6>3 \\
(p<0.05)\end{array}$ & $\begin{array}{l}3>1,4>1, \\
5>1,6>1 \\
(p<0.05)\end{array}$ & $\begin{array}{c}2>1,3>1,4>1, \\
5>1,6>1,5>2, \\
6>2,5>3,6>3 \\
\quad(p<0.05)\end{array}$ & $\begin{array}{l}2>1,3>1, \\
4>1,5>1, \\
6>1,6>2 \\
(p<0.05)\end{array}$ \\
\hline
\end{tabular}

Tablo 8'deki bulguların 1şığında, şu saptamalar yapılabilir: Araştırmaya katılan işyeri sahiplerinin işlerindeki deneyim süresi değişkeni açısından, ekonomi okuryazarlığı genel düzeyiyle birlikte tüm alt boyutların ortalama puanları arasındaki fark anlamlı bulunmuştur. Ayrıca, işyeri sahiplerinin öğrenmeye ilişkin tutum 
puanları ortalamaları da deneyim değişkeni açısından anlamlı bir farklılık sergilemiştir $(\mathrm{F}=7.247, \mathrm{p}=0.000<0.05)$. $\mathrm{Bu}$ analiz sonuçları, işyeri sahiplerinin hem ekonomi okuryazarlığı düzeylerinin hem de öğrenmeye ilişkin tutum puanlarının, iş deneyimleri arttıkça yükselebileceğini göstermiştir. Böyle bir sonuç, yaşamboyu öğrenme felsefesinin doğal gerekçelerinin doğrulanması niteliğindedir. Çünkü, birer yetişkin birey olarak işyeri sahipleri, işlerindeki tecrübeleri arttıkça, öğrenmeye daha açık ve istekli olarak ekonomi okuryazarlığı yeterliklerini artırma şansını yakalayabilmiş olmaktadır.

\section{Tartışma, Sonuç ve Öneriler}

Yukarıda sunulmuş olan bulgulara göre, araştırma problemlerinin ağırlıklı olarak olumlu yönde yanıtlandığı görülmektedir. İşyeri sahiplerinin öğrenmeye yönelik tutumlarının, ekonomi okuryazarlığına etkisi olduğu ve olumlu yöndeki öğrenme tutumunun ekonomi okuryazarlığını artırabileceği görülmüştür. Ayrıca, katılımcıların öğrenmeye ilişkin tutum puanları ortalaması, ekonomi okuryazarlığı puanlarının ortalamasından daha yüksek çıkmıştır. Bu durum, öğrenmeye açık bir kitlenin varlığına işaret eder.

İşyeri sahiplerinin yaşları, eğitim düzeyi ve işteki deneyim süresinin de ekonomi okuryazarlığına ve öğrenmeye yönelik tutumlarına etkisi olabileceği saptanmıştır. Başka bir deyişle, bireylerin öğrenmeye ilişkin tutum ve ekonomi okuryazarlığı düzeyi yaş, eğitim düzeyi ve iş deneyimi arttıkça yükselebilmekte veya tam tersi olarak birlikte düşebilmektedir. Bu durum, yaşa bağlı olgunlaşmayla açıklanabileceği gibi, günümüzün küreselleşme sürecinin gerektirdiği bilgi ve beceri donanımının farkına varabilme durumuyla da açıklanabilir.

Bu noktada vurgulanması gereken konu, ekonomi okuryazarlığı gibi, örgün eğitim sistemi dışındaki süreçlerle kazanılabilecek tüm okuryazarlık yeterliklerinin, bireylerin öğrenmeye dönük yaklaşımlarıyla bağlantılı olduğunu sergileyebilmektir. Çünkü, öğrenmeye ve yaşam boyu gelişime kapalı bir zihniyete sahip bireylerin, bu tür kazanımların dışında kalmasının maliyetini sosyo-ekonomik ve politik düzlemleriyle bir toplumun tümü ödeyebilmektedir. Nitekim, girişimcilik cesareti göstererek ekonomik bir rolü yüklenmiş olan bireylerin, aldıkları bireysel risk kadar, toplumsal yükümlülüklerinin de kritik düzeyde olduğu unutulmamalıdır.

Yetişkinlere dönük ekonomi öğretimi çalışmaları, Kim'in (2012: 195-200) çalışmasında ifade edildiği gibi, özellikle örgün eğitimin lise ve sonrası aşamalarından mahrum kalmış kadınlar ve göçmenler gibi dezavantajlı kesimler de dikkate alınarak programlanmalıdır. Çünkü, düşük eğitimli bireylerin ekonomik politikalara yönelik siyasal tercihleri ve tutumları, aslında kendi sosyo-ekonomik çıkarlarının bile aleyhine olabilmektedir. İşyeri sahipleri de, yüklendikleri üretim ve istihdama katkı rolleri nedeniyle, ekonomi okuryazarlığına dönük eğitim programlarının tasarlanması sürecinde hesaba katılması gereken kesimler arasındadır.

Türkiye ekonomisinin gelişiminde kilit rol oynayan işyeri sahiplerinin (girişimciler) öğrenmeye ilişkin tutumu ve ekonomi okuryazarlığıyla ilgili yeni araştırma önerileri ise şöyle özetlenebilir:

- İller bazında Ticaret ve Sanayi Odalarıyla ve/veya Türkiye İş Kurumu gibi kurumlar aracılığıyla ulusal düzeyde olmak üzere, tüm girişimcilerin/işyeri sahiplerinin öğrenme ihtiyaçları envanteri çıkartılabilir. Bu envanter, tüm okuryazarlık türlerine dönük eğitim programları müfredatının temeli olacaktır.

- Mahalleler ya da belediyeler düzeyinde projeler yoluyla, işyerlerinin yöneticilerine ve personeline dönük periyodik analizler uygulanarak bilgi ve beceri profillerinin değişimi izlenebilir. Bu profillerde daha eğitimli ve daha deneyimli olduğu saptanmış olan bireylerin, kendi öğrendiği ekonomik bilgileri diğer işyerlerindeki bireylere öğretmesini teşvik edici halk eğitim modelleri tasarlanabilir.

\section{References}

Akhan, N.E. (2013). Adım adım ekonomi okuryazarlığı: Sosyal bilgiler dersleri için alternatif yollar [Step by step economic literacy: Alternative ways for course of social studies]. Adlyaman Üniversitesi Sosyal Bilimler Enstitüsü Dergisi, 14, 1-36. Retrieved September 9 2017, from http://www.dergipark.gov.tr/download/articlefile/15122.

Aktürk, A.O. (2012). Öğretmen adaylarının öğrenmeye ilişkin tutumlarının öğretmenlik mesleğini tercih etme nedenlerine ve akademik başarılarına göre incelenmesi [A study on attitudes towards learning of prospective teachers according to the reasons to choose teaching profession]. Ahi Evran Üniversitesi Kırşehir Ë̆itim Fakültesi Dergisi, 13(3), 283-297. $\quad$ Retrieved $\quad$ September $7 \quad$ 2017, from http://www.acarindex.com/dosyalar/makale/acarindex-1423907548.pdf. 
Altunışık, R., Coşkun, R., Bayraktaroğlu, S ve Yıldırım, E. (2010). Sosyal bilimlerde ataştırma yöntemleri-SPSS Uygulamalı (6. bask1) [Research techniques for social sciences(6th edition)], Adapazarı: Sakarya Yayınc1lik.

Balc1, A. (2010). Sosyal bilimlerde araştırma (8. bask1) [Research for social sciences (8th edition)]. Pegem Akademi: Ankara.

Aydın, M. (2016). Examination of science teachers' attitudes towards learning by some variables. The Journal of International Lingual, Social and Educational Sciences, 2 (2), 75-84. Retrieved October 1 2017, from http://dergipark.gov.tr/download/article-file/285072.

Chang, W-Y. and Chang, I-Y. (2013). An investigation of students' motivation to learn and learning attitude affect the learning effect: a case study on tourism management students. Anthropologist, 16 (3), 457-463. Retrieved October 20 2017, from http://www.tandfonline.com/doi/abs/10.1080/09720073.2013.11891371.

Ergün, B.,Şahin, A. ve Ergin, E. (2014). Finansal okuryazarlık: İşletme bölümü öğrencileri üzerine bir çalışma [Financial literacy: A study on the students of business administration]. Uluslararası Sosyal Araştırmalar Dergisi, 7 (34), 847-864. Retrieved September 1 2017, from http://www.sosyalarastirmalar.com/cilt7/sayi34_pdf/8isletme_iktisat_iletisim_kamu/ergun_bahadir_vd.pdf.

Gerek, S. ve Kurt, A.A. (2011). Ekonomi okuryazarlığı ölçeğinin geçerlik ve güvenirlik çalışması [The study of validity and reliability of the scale of economic literacy]. Uludağ Universitesi Iktisadi ve İdari Bilimler Fakültesi Dergisi, $30 \quad$ (1), 59-73. Retrieved October 1 2017, from http://www.uludag.edu.tr/dosyalar/iibfdergi/genel-dokuman/2011_1/ASL04.pdf.

Jappelli, T. (2010). Economic literacy: An international comparision. The Economic Journal, Royal Economic Society, 429-451. Retrieved October 20 2017, from http://onlinelibrary.wiley.com/doi/10.1111/j.14680297.2010.02397.x/epdf.

Kahya, C. ve İmamoğlu İ.K. (2015). Ekonomi okuryazarlığının girişimcilik niyeti üzerindeki rolü [The role of economic literacy on intention of entrepreneurship. The Journal of Academic Social Science Studies, 39, 139156. Retrieved September 20 2017, from http://www.jasstudies.com/OncekiSayilarDetay.aspx?Sayi= Number:\%2039.

Kara, A. (2010). Öğrenmeye ilişkin tutum ölçeğinin geliştirilmesi [Developing of the scale of attitude towards learning]. Elektronik Sosyal Bilimler Dergisi, 32 (9), 49-62. Retrieved September 20 2017, from http://dergipark.ulakbim.gov.tr/esosder/article/view/5000068309.

Kao, Chia Pin and Tsai, Chin-Chung. (2009). Teachers' attitudes toward web based proffessional development with relation to internet self-efficacy and beliefs about web-based learning. Computers and Education, 53, 6673. Retrieved October 1 2017, from http://www.sciencedirect.com/science/article/ pii/ S03601315 090000 37?via\%3Dihub.

Kim, M. (2012). Teaching popular economics to less-educated adults: principles and examples for teaching heterodox and critical economics. On The Horizon, 20 (3), 194-205. Retrieved September 7 2017, from http://ecolit.weltgewandt-ev.de/wp-content/uploads/2017/04/Teaching-popular-economics-to-less-educatedadults.pdf.

Liaw, Shu-Sheng; Huang, Hsiu-Mei \& Chen, Gwo-Dong. (2007). Surveying instructor and learner attitudes toward e-learning. Computers and Education, 49, 1066-1080. Retrieved September 9 2017, from https://www.sciencedirect.com/journal/computers-and-education/vol/49/issue/4.

Mercan, N., Oyur, E., Altınay, A. ve Aksanyar, Y. (2012). Ekonomi okuryazarlığına yönelik ampirik bir araştırma [An ampirical research on economic literacy]. Ekonomi Bilimleri Dergisi, 4(2), 109-118. Retrieved October 1 2017, from http://dergipark.gov.tr/ebd/issue/4860.

Mersin Chamber of Trade and Industry, Profession Groups Table. Retrieved July 27 2017, from http://www.mtso.org.tr/en/a/mersin-contract-and-san-odasi-nin-mobile-groups-tablosu\#7.

North Central Regional Educational Laboratory-NCREL (2017). 21st century skills: Economic literacy. Retrieved September 9 2017, from http://www.careersmarts.com/21/engauge21st.pdf 
Schug, M. C., ve Hagedorn, E.A. (2005). The money savy pig goes to the big city: Testing the effectiveness of an economics curriculum for young children. The Social Studies, 96 (2), 68-71. Retrieved October 20 2017, from http://www.tandfonline.com/doi/abs/10.3200/TSSS.96.2.68-71.

Senemoğlu, N. (2009). Gelişim, ögrenme ve öğretim-kuramdan uygulamaya (14. baskı) [Development, learning and teaching-From theory to practice (14th edition)]. Ankara: Pegem Akademi.

Shih, Ju-Ling; Chu, Hui-Chun \& Hwang, Gwo-Jen. (2011). An investigation of attitudes of students and teachers about participating in a context-aware ubiquitous learning activity. British Journal of Educational Technology, 42 (3), 373-394. Retrieved September 9 2017, from http://onlinelibrary.wiley.com / doi / 10. 1111/bjet.2011.42.issue-3/issuetoc.

Sümbüloğlu, K. (1993). Biyoistatistik [Biostatistics]. Ankara: Özdemir Yayıncılık.

Şantaş, F. ve Demirgil, B. (2015). Ekonomi okuryazarlığı düzeyinin tespitine ilişkin bir araştırma [An investigation of level of economic literacy]. Akademik Bakış Dergisi, 48, 46-60. Retrieved September 9 2017, from http://www.akademikbakis.org/dergi//ekonomi-okuryazarligi-duzeyinin-tespitine-iliskin-bir-arastirma 201503.pdf.

Temizel, F. ve Bayram, F. (2011). Finansal okuryazarlık: Anadolu Üniversitesi İktisadi İdari Bilimler Fakültesi ögrencilerine yönelik bir araștırma [Financial literacy: A study on the students of the faculty of economics and administrative sciences of the University of Anadolu]. C. Ü. Íktisadi ve İdari Bilimler Dergisi, 12 (1), 73-86.

Turkey Tradesmen and Artisans Confederation (TESK) (2017). Merchants by Province, Housing, Population and Chamber Numbers. Retrieved November 2 2017, from http://www.tesk.org.tr/tr/calisma/sicil/4.pdf.

Ünal, S., Düğer,Y.S. ve Söylemez, C.(2015). Ekonomi okuryazarlığı ve kredi kartı tutumunun rasyonel kredi kartı kullanımına etkisi: Dumlupınar Üniversitesi Tavşanlı MYO örneği [The influence of economic literacy and attitudes of credit cards on using rationally of credit cards]. Eskişehir Osmangazi Üniversitesi İ̈BF Dergisi, 10 (1), 31-52. Retrieved September 1 2017, from http://iibfdergi.ogu.edu.tr/makaleler/13593624_101_NC4B0SAN202015_Makale_0.pdf. 